\title{
LOS PRIMEROS COLEGIOS JESUITICOS EN EL PAIS VASCO (S. XVI Y XVII)
}

\author{
Juan Iturriaga \\ Universidad de Deusto
}

\section{FUENTES}

En noviembre de 1767 los religiosos de la Compañía de Jesús residentes en España fueron expulsados por orden del rey Carlos III ${ }^{1}$. Entre las diferentes consecuencias que se siguieron a esta voluntad real, una muy importante fue el inventario o recuento de las posesiones y propiedades de los jesuitas al abandonar sus tierras originarias españolas.

Distintos oficiales de la burocracia borbónica se encargaron de esta tarea. En nuestro caso la responsabilidad recayó sobre don Juan Antonio Archimbaud y Solano, Contador principal de las Temporalidades ocupadas a los regulares de la Compañía de Jesús.

En el Archivo Histórico de Loyola (Azpeitia, Guipúzcoa) se encuentra un volumen manuscrito, cuya cubierta dice textualmente:

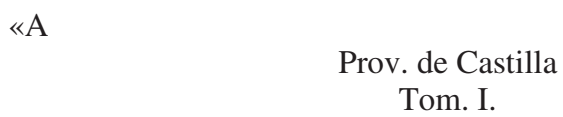

$\ll \mathrm{A}$

Prov. de Castilla

Tom. I.

Contiene XVII. Extractos de Fundaciones respectivas á las Cassas, y Colegios, que fueron de los Regulares expulsos de la Compañia llamada de Jesus en dicha Provincia de Castilla, con expresion de las Memorias, Obras pias, Patronatos, y llamamientos à varios Vinculos fundados en ellos; segun resulta de los documentos, y noticias de sus fundaciones pedidas por la superioridad del Consejo, à los Comisionados de dichos Colegios, y remitidas por la misma superioridad à la Contaduria de la Temporalidades ocupadas a dichos Regulares.

1 Rey de Nápoles a partir de julio de 1734 y de España desde 1759. Madrid 20.1.1716Madrid 14.12.1788. 
Dispuesto de orden de los Señores del Consejo Extraordinario.

Por

Dn. Juan Antonio Archimbaud, y Solano Contador principal de dichas Temporalidades.

Año de MDCCLXIX.»

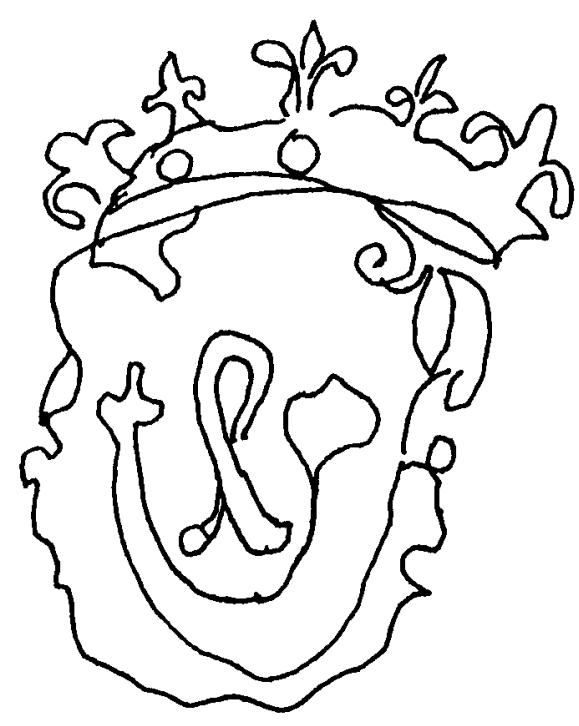

El escrito que sigue a esta barroca portada comienza con las iniciales mayúsculas $\mathrm{M}$ [uy] $\mathrm{P}$ [oderoso] S[eñor] y va dirigido a Carlos III como rey de España. Sin embargo, la orden le ha llegado al Contador de las Temporalidades por medio de los ministros reales don Pedro Rodríguez, Conde de Campomanes [Santa Eulalia de Sorribas, 1723-Madrid 1803] y José Moñino, Conde de Floridablanca [Murcia, 1727-Sevilla 1808] el 11 de diciembre de 1768.

Con una modestia sumisa confiesa la «cortedad de mi talento» y su decisión «sin mas ambicion $\mathrm{P}$ [oderoso] S[eñor], que ... mi ciega rendida obediencia», que inmediatamente se comprueba no es del todo sincera cuando llega a la conclusión de no haber llegado a la altura de los requerimientos reales, lo cual «no ha sido por mi culpa, ni por omisión mia», sino por el:

«irregular confuso metodo con que los Regulares expulsos llevaban sus Quentas, la absoluta falta de Libros de Casa, la ninguna coordinacion de sus Papeles, y recados de Justificacion, la confusión de sus respectivos In- 
tereses, con los de los estraños, el enlace de unas Memorias con otras, la inversion de las Rentas de muchos extablecimientos sin mas regla, ni objeto, que su particular combeniencia, la repetida suposición de Fidei Comisos, y la contradicion de muchas Notas, que se hallan en sus Libros».

Una vez que ha despejado el campo para cubrirse las espaldas en caso de error u omisión, comienza el Contador de Temporalidades a encomiar al Monarca, con términos que la historia se niega a $\operatorname{aceptar}^{2}$ como:

«amabilisimo soberano el señor D. Carlos III que Dios guarde: cuio sabio Dominio ha producido y produce tantas felicidades a sus vasallos, y cuia justicia ha merecido la admiracion de la Europa, y del Mundo entero...»

Pero viniendo al particular de la expulsión de los jesuitas, don Juan Antonio Archimbaud no tiene adjetivos para calificar la conducta de Carlos III:

«... por el modo christiano, sabio, y prudente, con que su Magestad ha arreglado toda su conducta, ni los expulsos, ni sus sequaces, por mas esfuerzo, que hagan podrán eclipsar sus heroicas virtudes, y aunque obstinados y ciegos en sus opiniones olviden el algun tiempo el respeto, que merecen sus R[eale]s Resoluciones, quedarán Documentos, que ... los obligen à callar».

De estos documentos históricos que deja Carlos III entre otros párrafos retóricos vacíos de sentido, creemos oportuno citar un último razonamiento con el que trata de justificar la conducta del monarca al expulsar a los jesuitas, por:

2 No es aquí el lugar apropiado para entrar en la valoración de tan espinosa cuestión como el gobierno de Carlos III, sin embargo creemos oportuno transcribir lo que la enciclopedia Espasa dice citando al historiador Gonzalo Reparaz: «Supo gastar [Carlos III] el dinero ahorrado por su hermano, pero no le imitó en su prudencia, pues firmó el Pacto de familia, que le obligó á apoyar á los indígenas de los Estados Unidos sublevados contra la Metrópoli, señalando á las posesiones españolas de América el camino de la separación. Gravísimo error suyo fué la expulsión de los jesuitas, promovida por la masonería, la cual había convertido á varios soberanos en instrumento suyo para la obra de iniquidad, falta que costó á los descendientes de aquellos reyes el trono y á algunos la vida, cuando la Revolución francesa». Y continúa con el testimonio de Sánchez Casado: «si consintió atropellos fué más por cortedad de entendimiento que por perversión de espíritu.» Enciclopedia Universal Ilustrada. Madrid, Espasa-Calpe, 1912. Tomo XI, pp. 1.038/1.039. Para que la información no sea del todo unilateral permitásenos aducir una traducción propia del juicio de la enciclopedia británica sobre este soberano: «Su política eclesiástica estaba condicionada por la decisión de someter completamente la Iglesia a la corona. No permitió en España, bulas papales o breves sin su autorización. Especialmente le molestaban los jesuitas por su organización internacional y por la fidelidad al papa, que consideraba como una afrenta a su absolutismo. No estaba seguro de su fidelidad a la corona en América y creía que habían tenido parte en los disturbios de Madrid y otros lugares en 1766.» Encyclopedia britannica. Chicago, William Benton, 1973. Volumen 5, p. 314. 
«... los infinitos beneficios, que resultaron de estas [providencias reales], y de verificarse religiosa, y plenamente el cumplimiento de las Cargas, segun la mente de los Fundadores, y el Real animo de su Magestad: quantas viudas socorridas quantas Huerfanas dotadas, cautibos redimidos, Pobres encarcelados por deudas, puestos en libertad, estudiantes, y Colegiales mantenidos, infinito numero de Cathedras, y escuelas, Misiones puestas en practica, Fiestas, Novenas, y una multitud de obras pias ...»

Pero esta abultada e imprecisa enumeración, le lleva al ilustre Contador de Temporalidades autor del presente tratado, a una conclusión un tanto sospechosa:

«... todo esto cuyo por menor es immenso (como lo manifiesta esta misma obra) y produce al estado los maiores beneficios, ...» ${ }^{3}$

Esta conclusión, a la que quizá inconscientemente ha llegado nuestro autor, pone un interrogante a todos los elogiosos antecedentes con que ha querido ilustrar la conducta de Carlos III al expulsar a los jesuitas, desposeyéndolos de todas sus propiedades.

Sin embargo no es el propósito del presente estudio buscar las razones, ni enjuiciar la conducta de Carlos III en un asunto tan complicado y difícil como la expulsión de los jesuitas, sino solamente tratamos de evaluar sobre la base del presente documento, la fundación de Colegios o Casas jesuíticas en terreno considerado hoy día de la Comunidad Autónoma Vasca y sus características peculiares.

Ha sido necesaria la precedente introducción para poder entender e interpretar algunas de las apreciaciones que puedan aparecer a lo largo del documento introducidas por el Contador de Temporalidades, don Juan Antonio Archimbaud y Solano, que firma todas y cada una de las páginas del grueso volumen, del que hemos entresacado solamente aquello que nos interesaba para ciertos colegios concretos.

\section{EL COLEGIO DE AZCOITIA}

\section{Instrumentos jurídicos de la fundación}

A la base de la fundación de este Colegio de la Compañía de Jesús está el testamento de Domingo Pérez Idiaquez, Secretario, y el de su esposa Catalina de Olano, que lleva la fecha de 12 de febrero de 1588. El escribano es Domingo de Zavala.

\footnotetext{
3 El subrayado es nuestro.
} 
Se abre el testamento el 22 de enero de 1599 ante el Alcalde Martín Pérez de Aizpurua, siendo escribano de número Domingo Sagastizabal.

Siendo ya viuda Catalina de Olano configuró un Codicilo con el escribano de número Juan de Oyangueren el 7 de mayo de 1593. Catalina de Olano pertenecía a la familia de San Ignacio de Loyola, era sobrina de Catalina de Loyola y su heredera universal, como veremos en algunos detalles que adjuntamos.

Según estos documentos Domingo Pérez Idiaquez y Catalina de Olano,

«... dejaron por su unico, y Universal heredero al Colegio, que la Compañia de Jesus disponían se fundase de sus bienes y Rentas en la nominada villa [de Azcoitia].»

El P. Juan de Montemayor S.J. ${ }^{4}$, Provincial de la Provincia de Castilla la Vieja, aceptó esta fundación y herencia en Salamanca a 6 de abril de 1599 ante Antonio Ruano, escribano de número de dicha ciudad.

\section{Las condiciones económicas}

Los Fundadores dejan al Colegio de la Compañía de Jesús las siguientes rentas:

Las casas principales con su torre que los Fundadores tienen en Azcoitia. Las del Vicario Argarain, la torre y las heredades de Itugarte, con sus molinos, nogales, heredades, manzanos, jarales y demás derechos, la casa y casería de Olaran con todas sus heredades, castañales, montes, prados, pastos, todo lo demás anexo y todo su ganado, la casa y casería de Zuloeta con sus montes, castañales, prados, pastos y todo su ganado, la casa y casería de Apalasagasti, con sus manzanos, castañales, heredades, montes y ganado.

En dinero por la casa de Marcos Fucar, 400 ducados de renta a 14 el millar. Otros 200 ducados de los censos contra la villa de Madrid, Blas Samaniego, Pascual López, Alonso Romano, otros vecinos de la villa de Cienpozuelos y contra otras personas.

Según Archimbaud la renta de la que ha gozado el Colegio de Azcoitia ha sido cinco mil reales poco más o menos.

Las condiciones que pusieron los Fundadores en el aspecto económico fueron que no se podían aplicar las rentas destinadas a este Colegio de Azcoitia a otro Colegio.

En caso de contravenir la Compañía de Jesús lo dispuesto, que se gastasen las rentas y bienes en erigir un monasterio de frailes.

\footnotetext{
4 Johannes de Montemayor [Ceniceros 1560 - † después de 1636 y antes de 1642].
} 
Si el Colegio heredase otros bienes, los debe vender inmediatamente y emplear su importe en renta. No puede tener más bienes raíces que los concedidos por los Fundadores.

\section{Número de jesuitas y obligaciones de los mismos}

Con las rentas que se le conceden al Colegio de Azcoitia, la Compañía de Jesús tiene que poner diez jesuitas, 7 padres y 3 hermanos, sin que obste, en el caso de aumentarse la renta, que este número de jesuitas aumente.

Sus obligaciones son para dos padres:

«... que el uno enseñe á los Niños de dicha villa [Azcoitia], y fuera de ella, á léer, escrivir, y la Doctrina christiana, y que sea en castellano, para que mejor se perfeccionen en la lengua castellana .... ${ }^{5}$

El otro debía enseñar gramática y retórica.

\section{Mandas piadosas}

Exigen los Fundadores ser sepultados en la Iglesia del Colegio precediendo misa cantada y responso. La víspera del día de los difuntos, se debían tener vísperas y un nocturno. El mismo día de ánimas o de difuntos 6 se debe decir perpetuamente una misa cantada y con su responso:

«... por sufragio de la Anima del señor Rey Dn. Phelipe II, y de los Fundadores, y de sus Difuntos, y en las demas oraciones, que se aplican en los Colegios por los Fundadores, se tenga particular cuidado de pedir a Dios por S[u] M[ajestad].»7

Por su parte Catalina de Olano, en su codicilo mencionado más arriba, pone a los jesuitas la obligación en perpetuidad de decir tres misas rezadas por los Fundadores y difuntos de sus familias el domingo de la Trinidad.

${ }^{5}$ Fol. 45r. El subrayado es nuestro. La intención del subrayado va dirigida al lector para que no se le pase por alto el deseo de una familia adinerada vascongada con relación a la lengua castellana y la necesidad de que en villas enteramente vascongadas se aprenda el castellano.

6 La fiesta de todos los fieles difuntos, que en aquel tiempo y aún hoy día en algunos lugares se llama fiesta de ánimas, se celebra actualmente en la Iglesia católica el día 2 de noviembre.

7 Fol. 46r. El subrayado es nuestro. Hemos querido resaltar el detalle para poner de relieve la fidelidad al rey de España por parte de tan poderosos señores del País Vasco en el siglo XVI. 


\section{Relaciones con las Parroquias de Azcoitia y Azpeitia}

Catalina de Loyola nombró en su testamento realizado en Madrid con fecha del 9 de mayo de 1574 ante Cristóbal Riaño, escribano de número, heredera a su sobrina Catalina de Olano. Siguiendo el deseo de su tía, Catalina de Olano mandó que se pongan 50 ducados de renta cada año a 14.000 el millar, de los censos que le dejó su tía para fundar en la parroquia de Azpeitia una capellanía con misa cantada y sacristán. Y mientras se tramita esa renta de Catalina de Loyola, ordena que se paguen los gastos de los bienes de dicha heredera, Catalina de Olano.

Por otro lado la obligación que impuso esta señora fundadora a los jesuitas de tres misas rezadas el domingo de la Trinidad, mientras no se construyese la Iglesia del Colegio, manda que se digan en la Parroquia de Azcoitia, «dando la limosna acostumbrada.» ${ }^{8}$

Pero donde más sobresalen las relaciones respetuosas y amigables, que deben reinar entre los jesuitas beneficiarios de la herencia de los fundadores y las parroquias, es cuando éstos disponen el traslado de sus cuerpos después del fallecimiento y los de sus antepasados de la Parroquia de Azcoitia donde están sepultados a la Iglesia del Colegio de la Compañía de Jesús:

«... sin que por eso adquieran derecho de sepultura los Patronos, que dejan nombrados, pues no quieren perjudicar en sus derechos al Cavildo eclesiástico.»9

\section{Conclusiones}

Los documentos relativos a la fundación del Colegio de Azcoitia, tal como nos los transmite el Contador de Temporalidades, don Juan Antonio Archimbaud y Solano, reflejan una gran generosidad por parte de los fundadores.

Resalta su deseo de que los jesuitas beneficiarios de la herencia oren por ellos y sus antepasados con obligaciones de misas y otros rezos.

Es notable la inclusión en estas oraciones, unas en favor del fallecido Felipe II, rey de España ${ }^{10}$, cuya mención no parece ser obligada por ninguna costumbre sino por simple respeto a quien ha regido la nación.

La última nota que queremos resaltar es el propósito de los fundadores de que en tierras vascongadas se aprenda el castellano y se procure la educación clásica de sus moradores.

\footnotetext{
8 Fol. 49v.

9 Fol. 45v. El subrayado es nuestro.

10 Valladolid 21.5.1527-El Escorial 13.9.1598.
} 


\section{EL COLEGIO DE BILBAO}

\section{Instrumentos jurídicos de la fundación del Colegio}

El fundador de este Colegio de Bilbao es Domingo Gargolla. En Alcalá a 23 de julio de 1602 hizo testamento cerrado ante Alonso Collado, escribano. Se abrió el 29 de agosto de 1604 ante Felipe de Castillo:

«... entre otras obras pias, que dejo dispuestas, mandó fundar el Colegio de la Compañia en dicha villa de Bilbao, su Patria ...»11

Le fueron adjudicados al Colegio los bienes legados el 11 de diciembre de 1614 ante el escribano Felipe Pérez del Castillo.

\section{Condiciones económicas}

La dotación se hizo principalmente por juros ${ }^{12}$ :

—En Valladolid a 1 de abril de 1606. Juros en Salinas de Atienza.

—En Valladolid a 27 de octubre de 1605. Juros en Salinas de Añana.

-En Salinas de Asturias.

- Sobre los Maestrazgos de Santiago despachados en Madrid a 22 de diciembre de 1611.

-En las Salinas de Cuenca.

-Dos juros distintos en puertos secos de Castilla.

- Por las alcabalas de la villa de Arévalo.

- Bienes propios de Domingo de Gargolla.

Balance final de los bienes cedidos al Colegio de Bilbao por Domingo Gargolla

Todo lo cual viene a significar:

-1.500 ducados de renta anual

Por los juros citados más arriba y en el mismo orden:

-2.160.000 maravedíes a razón de 20.000 el millar, que importan 108.000 maravedíes

11 Fol. 52v.

12 Derecho perpetuo de propiedad o pensión perpetua que se concedía sobre las rentas públicas. 
-2.170.000 maravedíes

-1.912 .500 maravedies

-2.400 .000 maravedíes

-810.560 maravedíes

- 174.000 maravedíes

-297.500 maravedíes

- 104. 600 maravedíes

Todo lo cual llega a la cifra de 7.977.160 maravedíes por los juros.

Además 705.000 maravedíes de las rentas del capital de Domingo Gargolla.

El destino que este bienhechor del Colegio de Bilbao le impone son las siguientes obligaciones:

—En general ejercitar los ministerios propios de la Compañía de Jesús según sus constituciones.

-En cuanto al número de religiosos que residan en el Colegio, lo deja a juicio del P. General de la Compañía de Jesús.

- Del dinero legado se ha de emplear 20.000 maravedíes en sacar presos de la cárcel de Bilbao, preferentemente si son parientes del fundador ${ }^{13}$.

-30.000 maravedíes en socorrer a tres viudas, familiares del fundador. A cada una 10.000 maravedíes.

- Pero el fondo entero donado se destina a la subsistencia del Colegio, no se puede utilizar sino para su fundación, sin que se pueda enajenar nunca.

\section{A. La Villa de Bilbao y el Colegio de la Compañía de Jesús}

La Villa de Bilbao añadió inmediatamente unas ayudas económicas con la función de abrir unos estudios de gramática. Para ello se otorgaron cuatro escrituras.

\section{Primera escritura}

El 26 de mayo de 1611 ante Diego de Avendaño se le adjudican al Colegio 1.600 ducados a 200 cada año. Además 400 ducados que dio la

13 Es curioso observar la cautela del presente bienhechor por un posible fraude que podría surgir al imponer al Colegio esta obligación de atender a los presos preferentemente familiares del fundador, porque añade la claúsula: «... pero si acaso entrase el tal Pariente [del fundador], artificiosamente por gozar de esta limosna, no se diese á este, sino a los demas Presos que se hallasen en dicha Carcel, por la causa referida.» Fol. 56r. 
villa por una sola vez. El destino de estos fondos es abrir unos estudios de gramática en el Colegio ${ }^{14}$.

\section{Segunda escritura}

Ante Andrés de Pagoeta el 20 de octubre de 1613. Se obliga al que sea Rector del Colegio a mantener perpetuamente esta cátedra de gramática. Pero por su parte la villa:

«... constituyendose, como debia constituir la villa, à no tener otro Maestro, que enseñase Grammatica, à cuya obserbancia se obligó dicha villa.» ${ }^{15}$

\section{Tercera escritura}

Se hizo el 16 de noviembre de 1636 ante el escribano de la villa Gonzalo de Lopategui. La villa adjudica al Colegio para el mantenimiento de la citada cátedra 150 ducados de vellón de renta para cada uno de los maestros, durante 12 años, todos los años. Se exigía también a los jesuitas la aceptación de estas cláusulas. El P. General mandó la confirmación correspondiente el 24 de octubre de 1637.

\section{Cuarta escritura}

Es la aceptación ${ }^{16}$ que hacen los jesuitas el 2 de junio de 1650 ante Pedro Basaran, escribano de la villa, de los 1.800 ducados que dicha villa se había obligado a entregar en total durante 12 años.

\section{B. Dotación del Contador Ochoa de Urquiza y su esposa Antonia de Zamudio}

El contador y su esposa hicieron donación ante Domingo de Varrutia, escribano de número de la villa el 4 de julio de 1618:

«... a favor de este Colegio, de los Bienes del expresado Contador Ochoa de Urquiza ... con las cargas y obligaciones que expresa ...»17

14 La óptica de la villa con respecto a esta enseñanza no se reduce a los vecinos de la misma, exige mantener en el colegio: «... estudios de Grammatica, con dos Maestros para la enseñanza de todos los estudiantes naturales, y forasteros, que asistiesen, como tambien la Doctrina Christiana à la Juventud graciosamente por espacio de 8 años ...» [Fol. 57v]. El subrayado es nuestro.

15 Fol. 58v.

16 En el lenguaje de la época se llama a este documento financiero: «carta de pago».

17 Fol. 60v. 
Pero esta legación fue impugnada por el Cabildo eclesiástico y las autoridades civiles de la villa de Lequeitio y de la anteiglesia de Zamudio, con el resultado de una sentencia pronunciada el 16 de marzo de 1625 , en la que se dio «por ninguna, y de ningun valor ni efecto» ${ }^{18}$. Dicha sentencia se confirmó por otra posterior del 15 de enero de 1627, en la que se determinaba la construcción en el Colegio de los jesuitas de una capilla, con acceso a la Iglesia, retablo en el altar mayor y dos altares colaterales. Dos capellanes diocesanos (no jesuitas) debían de celebrar en ellos las misas que el citado Contador había detallado ${ }^{19}$. Para ello destinaba 1.000 ducados anuales perpetuamente. Esta sentencia se volvió a confirmar por otra en Valladolid a 26 de julio de 1627.

Se aplicó en forma de juros de los bienes del Contador Ochoa de Urquiza al Colegio de la Compañía de Jesús de Bilbao 11.000 reales de vellón anuales.

\section{Condiciones económicas del Contador Ochoa al Colegio}

La capilla se edificó, pero no se pudieron encontrar capellanes para cumplir con las obligaciones que exigía el Contador, porque la cantidad de 200 ducados de vellón que la Cancillería había señalado para 610 misas al año. Pero los jesuitas asumieron la obligación y la cumplían siempre que cobraban la renta.

Los 1.000 ducados anuales se invirtieron en juros y censos, porque su valor había disminuido notablemente, siendo consecuentemente la renta producida muy baja.

\section{Donación de Miguel de Ogirondo, Alguacil Mayor del Consejo Real}

El 7 de abril de 1645 se abrió su testamento ante Francisco Suárez de Rivera, escribano de número de la villa de Madrid. Con esta escritura encargaba al Rector del Colegio la administración como Patrono de algunas obras pías.

Pero esa fundación se aminoró en su renta a 209 reales anuales de vellón.

${ }_{18}$ Fol. 60v. De este asunto pormenorizado haremos mención más adelante cuando tratemos de la fundación del Colegio de Lequeitio.

19 Cada uno de los capellanes debía de decir 25 misas rezadas al mes perpetuamente, en verano entre las nueve y once la mañana, y en invierno entre las diez y once de la mañana. Se debían de hacer sonar las campanas al propósito. Además al año debían cantar ocho misas, dos en la fiesta de la Santísima Trinidad y una en la octava del Corpus. Otras seis en festividades de la Virgen María, una el día de S. Francisco y otra en el de S. Benito. Estas dos últimas cantadas, con diácono y subdiácono, siendo precedidas en el día anterior por vísperas solemnes. 


\section{Condiciones económicas de Miguel Ogirondo}

Dejó un juro de 14.206 reales de vellón de renta anual, a razón de 20.000 el millar. 1.660 reales de vellón anuales en favor del Rector del Colegio de la Compañía de Bilbao por el trabajo y ocupación que le llevaría la administración de las obras pías que dejó dispuestas este bienhechor en las Iglesias de San Juan del Molinar y de San Nicolás de Zaldo, además de otras disposiciones.

\section{Elvira de Landecho, viuda de Bernavé}

Por una cláusula del testamento, que se otorgó el 28 de mayo de 1650 y se abrió el 1 de marzo de 1651 ante Martín de Eizaga, escribano de número de la villa de Bilbao, la Sra. Elvira de Landecho dejó al Colegio de la Compañía de Bilbao por una vez 500 ducados, para que las misas que se celebrasen en la Iglesia del Colegio en la Fiesta del Corpus se aplicasen por su alma, y para que se le incluyese en la lista de bienhechores del Colegio.

\section{E. Pedro de Hernani, cura natural de Ceberio}

Don Pedro de Hernani era cura de Mingorria y se comprometió con el P. Francisco Vallesteros ${ }^{20}$, Rector del Colegio de Bilbao, en escritura del 17 de febrero de 1691, a pagar de una vez 6.000 ducados, 4.000 de ellos para la redención de cautivos, y los otros 2.000 dejándolos a la discreción del Colegio, con tal de que le diese cuenta de la aplicación del dinero.

Pedía que con tales rentas se mantuviera una cátedra de Moral en el Colegio:

«... para el aprovechamiento y enseñanza, asi de todos los hijos naturales del señorio, como de qualesquiera partes, que quisiesen asistir, sin que se pudiese poner ninguna repugnancia, ni excusa por parte del Colegio.»21

Igualmente, que dos jesuitas saliesen de misión durante 20 días, especialmente en los valles de Ceberio y Orozco, de donde provenía el donante ${ }^{22}$.

Pedía para la cátedra de Moral y misión citada otros dos jesuitas. Uno para la cátedra y otro con el oficio de operario, compaginándolo, cuando llegase el tiempo, con la misión antes mencionada.

20 Franciscus de Ballesteros [Villanona 22.11.1653 - † después de 1700 y antes de 1705].

${ }^{21}$ Fol. 69v.

22 Fol. 70r: «... el dicho Dn Pedro de Hernani natural de los Valles de Zeuerio, y el de Orozco, para que estos gozasen de este bien espiritual, los dichos dos Religiosos huviesen de hacer dicha Mision a los naturales de áquellos valles...». 
El Colegio empleó los 6.000 ducados en redimir varios censos, que tenía contra sí.

\section{F. Ana María de Recalde y Coscojales, esposa del Marqués de Villareal (Francisco Díaz Pimienta)}

Por una cláusula de su testamento, otorgado el 8 de enero de 1699 y abierto el 13 del mismo mes ante el escribano de número de la villa de Bilbao Manuel de Bolivar, dejó al Colegio de la Compañía de Jesús de Bilbao de una sola vez 500 ducados de vellón, con la obligación de mantener tres lámparas en la Iglesia del Colegio, una que mandó hacer para el altar de $\mathrm{S}$. Francisco y otras dos que estaban ya colocadas en las capillas de la Concepción y de S. José.

\section{G. Legado de Juan de Larragoitia, nativo de Bilbao}

Incluyó este bilbaíno una cláusula en su testamento otorgado el 3 de marzo de 1704, que se abrió el 7 de febrero de 1707 ante Pedro Francisco de Garaitondo, escribano de número de la villa de Bilbao, dejando al Colegio de la Compañía de Jesús 12 ducados de vellón de renta anual con la finalidad de que hubiera una bujía de aceite día y noche ante la imagen y altar de S. Ignacio de Loyola, que estaba en el crucero de la Iglesia del Colegio a la parte del Evangelio.

\section{H. Legado de Miguel Vélez de Larrea, natural de Bilbao}

La escritura se otorgó en Valladolid el 28 de octubre de 1709 y actuó en nombre del donante, el obispo de Valladolid, don Andrés de Orueta y, de parte jesuítica, el P. Bernardo Peralta ${ }^{23}$, Rector del Colegio de S. Ignacio en la ciudad de Valladolid, con el poder del P. Fernando de Navarrete ${ }^{24}$, Rector del Colegio de Bilbao. Se concedía al Colegio de la Compañía de Jesús de Bilbao por una sola vez 2.000 doblones de a 60 reales cada uno, que son 120.000 reales de vellón.

La fundación instituía tres cátedras de Artes con tres sujetos más de los que existían y se enseñasen las súmulas, lógica, física y metafísica:

«... residiendo todo el año los nominados tres Maestros y cada uno en este Colegio, para que se empleen en el bien de las Almas de los naturales de la nominada villa de Bilbao, y del señorio de Vizcaya ....»25

23 Bernardus Peralta [Tuy 1.11.1646 - † después de 1705 y antes de 1714].

${ }^{24}$ Ferdinandus Navarrete [Madrid 26.3.1650 - después de 1714 no se tienen noticias de él].

25 Fols. 74v y 75r. 
A esta labor académica se unía la obligación de celebrar unas fiestas anuales los días de los Desposorios de S. José, el Dulce Nombre de María y el de la Aparición de San Miguel.

El Colegio recibió los 120.000 reales de vellón y asumió la obligación sometiéndose a todo el rigor del derecho.

Estos 120.000 reales los empleó el Colegio en tres casas nuevas, que mandó construir contiguas a los muros del Colegio.

\section{Legado de Sánchez de Veitia, viuda de Pedro de Hoz, vecina} de la villa de Bilbao

El testamento se otorgó el 23 de marzo de 1583 y se abrió el 4 de junio del mismo año ante el escribano de número de la villa de Bilbao Lope García de Meñaca.

El Colegio tomó posesión el 13 de noviembre de 1711 ante Antonio de Hostendi, escribano de número de la villa de Bilbao, de unas casas situadas en la calle Carnicería Vieja, que declaraba la testadora le habían costado 1.000 ducados de vellón.

\section{Obligaciones del Colegio de la Compañía de Jesús en Bilbao}

Las obligaciones que contraía el Colegio por esta donación eran, primero, en la Iglesia de San Vicente de Bilbao, celebrar perpetuamente una misa cantada el segundo día de Pascua de Resurrección con responso por la fundadora y sus familiares, con una dotación de seis reales de plata cada año.

En segundo lugar, otra misa cantada en la Iglesia de S. Pelayo de Guibelorzaga en el valle de Baquio, por eterno descanso de Lucía de Barcena, madre de la fundadora, con una dotación anual de siete reales de plata.

En último lugar, que se rezase un «placebo» y responso sobre su sepultura en la Iglesia de San Antón de Bilbao, pagando al Cabildo y Beneficiarios cuatro ducados cada año. Esta última manda se suprimió por escritura pública otorgada el 26 de abril de 1716, ante Antonio de Faño, escribano de número de la villa de Bilbao. Por esta razón ya no se realiza ni se cobra por el Colegio.

\section{J. Legado de Mateo de la Vía}

Según escritura del 8 de abril de 1714 dejó Mateo de la Vía a favor del Colegio de la Compañía de Jesús en Bilbao, 50 ducados anuales con la finalidad de que se tenga una misión todos los años en el valle de Arcentales. 
Una nota adicional nos advierte que esta dotación nunca se percibió y que por tanto la misión no se ha tenido en muchos años.

\section{K. Legado de Francisco de Rentería vecino de Madrid y natural de la anteiglesia de Baquio}

Se otorgó la escritura en Valladolid a 23 de diciembre de 1733 ante Luis Medina Mieses, escribano de número de la ciudad de Valladolid, en la que el fundador dejaba al P. Rector del Colegio de la Compañía de Jesús ${ }^{26}$ de Bilbao como patrono de ciertas obras pías.

\section{Dotación económica}

- Un censo de 4.000 ducados de principal y 120 de renta al año según escritura ante el escribano Juan José Tugo del 23 de mayo de 1733.

-15.000 ducados, 2.000 de los cuales por orden del P. Provincial de Castilla de la Compañía de Jesús, Manuel de Prado ${ }^{27}$, estaban en poder del Procurador General de dicha Provincia ${ }^{28}$, para invertirlos en la compra de una casa que serviría de habitación del preceptor de gramática. Los 13.000 ducados restantes se colocaban en un censo a razón de 2 y $1 / 2$ sobre unas fincas. Con el producto anual de dicho censo por cien se debían pagar diversas obras pías, que especificaba el donante. Vienen referidas seguidamente.

\section{Obligaciones del Colegio}

El P. Rector sería el árbitro para que hubiese perpetuamente una escuela de leer, escribir, contar y enseñanza de niños de la feligresía de Basigo y San Pelayo de Baquio, teniendo los parientes del fundador derecho a libros, papel, plumas y tinta del fondo de la renta según el parecer del P. Rector del Colegio. Tenía que enseñar todos los días de trabajo, por la mañana y por la tarde, a leer, escribir y contar. Pero los sábados por la tarde debía dar catecismo o doctrina cristiana.

El maestro contratado utilizaría del usufructo de la casa llamada de Ibarra de Arriba que habitaba, y se le pagarían anualmente 120 ducados de los intereses que produjesen los bienes del testamento del fundador.

\footnotetext{
26 Johannes Mathe [Del Valle, Segovia 22.2.1681 - † después de 1761 y antes de de 1767].

27 Emanuel de Prado [Valderensis, diócesis de Lugo 7.9.1675 - la última noticia que tenemos de él es en el catálogo de Castilla del año 1743].

28 Franciscus Nieto [Valladolid 20.1.1686 - † después de 1761 antes de 1765].
} 
La escuela de gramática para la enseñanaza de la juventud debía de estar abierta a los hijos de ambas feligresías citadas ${ }^{29}$ y descendientes del fundador, aunque fuesen de otros lugares.

Dichos preceptores de la escuela y de gramática debían de celebrar misa todos los días de fiesta en la Iglesia de Santa María de la anteiglesia de Basigo, con la intención de la misa libre. No podía faltar a clase los días señalados, a excepción de los libres o de vacación que señalase el Patrono. Si el maestro no cumplía estas condiciones el Patrono tenía que sustituirle por otro, percibiendo en ambos casos 150 ducados anuales de renta por la enseñanza.

Debían de acudir al trabajo personalmente, corriendo de su cuenta en caso de no poder hacerlo el buscar sustitutos o, en su defecto, el Patrono señalaría personas idóneas descontándoles a los maestros de la donación que les habían asignado para pagar a los que les sustituían. Aparte de todo lo dicho, los maestros tenían la condición de que:

«... no pudiesen tener, ni consentir en sus casas, tráfico vino ni otra especie de granjeria, en cuyo caso los pudiese remover el Patrono [= el Rector del Colegio] .... ${ }^{30}$

El Colegio de Bilbao debía enviar a la anteiglesia de Baquio y de Basigo dos jesuitas destinados por el P. Rector para celebrar una misión. En recompensa de tal trabajo, el Colegio gozaría de una renta anual de 80 ducados de vellón.

De los fondos legados, 30 ducados son destinados a cartillas, papel, tinta y plumas, «que no se entregase a los maestros en dinero, sino efectivamente en dichas especies $»^{31}$.

Se debía invertir 10 ducados anuales de renta para la conservación y reparación del edificio para la enseñanza de la gramática, y 30 ducados para libros, papel, tinta y plumas. Solamente el P. Rector del Colegio de Bilbao era el único responsable para nombrar los maestros de gramática y de la escuela. Por este patronato debía de percibir 20 ducados de vellón. Pero tenía que elegir el P. Rector los sujetos más idóneos:

«... sin que por empeño alguno se pudiesen conferir dichos empleos, si no es en áquellos que en conciencia, y en la Ley de Dios, le pareciesen mas a proposito a dicho P. Rector, pudiendolos remover este, siempre que huviese descuido y negligencia, en el cumplimento de su obligación.» ${ }^{32}$

29 De las dos anteiglesias de Basigo y San Pelayo de Baquio.

30 Fol. 86r.

31 Fols. 86v y 87r.

32 Fol. 88r. 
Para el Procurador del Colegio por el trabajo que le llevaban todos estos trámites se le aplicaban 15 ducados anuales de renta.

Una vez pagadas las disposiciones anteriores, 20 ducados del dinero restante, si hubiese, de 30 ducados se dedicaría a la reparación de las casas. Otros 10 ducados anuales para los libros, papel, tinta y plumas, y estuviesen depositados en el Colegio jesuítico de Bilbao. Si por el transcurso del tiempo dicha renta fallase, en primer lugar se suprimiese la misión, pero no la cátedra de gramática y escuela de niños.

Estas fundaciones fueron aceptadas por el Procurador General de la Provincia de Castilla la Vieja, P. Francisco Nieto.

\section{Legado de Juan Fernando de Ugarte Araiz, Zaldivar y Mallea como testamentario de Manuel de Diago y Mendi, vecino de Bilbao}

Por una escritura otorgada el 16 de septiembre de 1739 ante Joaquín de la Concha, escribano de número de la villa de Bilbao, ofrece por una vez 9.500 pesos de a 15 reales de vellón cada uno, que aceptó el P. Antonio Estañan ${ }^{33}$, Rector entonces del Colegio de Bilbao.

\section{Obligaciones del Colegio}

«Que en este Colegio hubiese de subsistir perpetuamente un Religoso sacerdote, Confesor, Bascongado, de la misma Religion de la Compañía, que no tubiese otro oficio, ocupacion, ni Ministerio, que el del Confesonario, y conversion de las Almas de dicha villa de Bilbao, y su direcion espiritual a la perfeccion christiana ... que fuese independiente del número de los que en áquel entonces, subsitian, y podrian subsistir en este Colegio ... el que huviese de servir esta obra pia subsistiese perpetuamente solo con el destino de ella.»34

El P. Rector del Colegio, Juan Antonio Estañan con permiso expreso del P. Francisco Rabago ${ }^{35}$, Provincial, aceptó esta obligación, que fue aprobada por el P. General de la Compañía de Jesús, Franciscus Retz ${ }^{36}$.

33 Johannes Antonius Estañan [Corella 1.2.1684 - el último catálogo de Castilla en que aparece es del año 1761].

${ }^{34}$ Fols. 92v y 93r. Hemos querido transcribir todo el texto para dejar patente la mentalidad del fundador que desea el cultivo de las almas que hablan el idioma vascongado. De este detalle se desprende que en la fecha de la donación (14 de enero de 1740) había necesidad en Bilbao de confesores y directores de almas que conociesen el idioma vascongado y pudiesen aplicarlo en los ministerios apostólicos. Que no era un simple capricho inútil del fundador se desprende de la aceptación de esta carga apostólica el 7 de noviembre de 1739 por el P. General de la Compañía P. Francisco Retz [Praga 1672-Roma 19.11.1750].

35 Franciscus de Rábago [Palacionensis, diocesis palentinae 4.10.1685].

36 Franciscus Retz [Praga 1672-Roma 19.11.1750]. 


\section{EL COLEGIO DE LEQUEITIO}

\section{Fundadores}

Otorgaron escritura de fundación ante Domingo Goena, escribano real y de número de la villa de Lequeitio, con fecha 28 de diciembre de 1688 , el Capitán José Mendiola y María Pérez de Bengoolea, su esposa:

«... al P. Andrés de Zupide ${ }^{37}$ Religioso de la Compañia de Jesus en virtud de Poder del P. Andres Reguera ${ }^{38}$ su Provincial en la de Castilla la Vieja (que otorgo en Villagarcia de Campos en 17 de Diciembre de 1688 ante Antonio Minayo) para la Fundacion de dicho Colegio de Lequeitio ...» ${ }^{39}$

\section{Dotación económica}

- 25.032 ducados y medio en capitales de censos.

-6.000 ducados de sus corridos.

- 18.000 ducados que valen las casas de su habitación, con su huerta, en Lequeitio.

-4.000 ducados de plata labrada.

-1.500 ducados en telas de oro, plata y ropa blanca.

-1.500 ducados en alhajas de casa.

Todo ello monta 56.032 ducados y medio

Además, hicieron donación de 6 cálices de plata con sus patenas, un crucifijo de marfil de la China, con sus remates de plata y cruz de ébano, un Niño Jesús vaciado de bronce.

300 ducados que costaron dos solares de casas, el uno contiguo al Colegio en la calle en Medio y otro a la entrada de la calle.

\section{Obligaciones del Colegio}

El título de la Iglesia ha de ser perpetuamente de S. José.

Los fundadores que tengan los honores, gracias, privilegios y sufragios propios de su cargo.

Serán los patronos del Colegio perpetuamente.

37 Andreas de Zupide [Vergara 4.5.1644-no aparece en ningún catálogo de Castilla después de 1696].

38 Andrés de Reguera [Lanimotensis, diocesis palentinae 18.11.1626-su nombre se encuentra por última vez en el catálogo de Castilla de 1700].

${ }^{39}$ Fol. 160v. 
El día de S. José, patrono y titular en la Iglesia del Colegio, se debe celebrar una misa cantada con sermón «ofreciendo a los Patronos en dicha Missa la vela».

El día de la Natividad de Nuestra Señora en la misma Iglesia se tendrá misa cantada con sermón.

El Colegio ha de enseñar públicamente gramática latina:

«tanto a los hijos de Lequeitio, como a los demas, que concurriesen.» 40

Si con el tiempo aumentan los religiosos y la renta resulta más que suficiente para las tareas siguientes, que se abra una cátedra de Teología Moral.

En el caso de que faltase la renta de 100 ducados que la Villa de Lequeitio aplicó de las obras pías del Contador Ochoa de Urquiza para una escuela de leer, escribir y contar y para un segundo Maestro de gramática, que se suprima esta última:

«... atento, a que esta [la escuela de leer etc...] es mas necesaria en aquel Pueblo.» 41

Que se entierre a los fundadores en el presbiterio de la Iglesia del Colegio al lado del evangelio.

Que en la fachada de la Iglesia se pongan los escudos de armas de los fundadores.

Que desde el día en que se ponga el Santísimo Sacramento en la Iglesia, que «haya de arder una Lampara de Aceyte, de día y noche perpetuamente.»42

En caso de que los jesuitas intentasen enajenar algunos de estos bienes de fundación, que la hacienda correspondiente pase al Convento de Dominicas de Lequeitio para que lo gocen perpetuamente.

Por lo que toca a las casas donadas, que nunca se vendan, sino que sirvan de Hospedería a los Dominicos y, en su defecto, para Hospital de la villa de Lequeitio.

\section{Dotación económica de la villa de Lequeitio para la escuela de primeras letras}

La villa de Lequeitio el 28 de diciembre de 1688, ante Domingo Goena, escribano real y del Ayuntamiento de ella, aprobó la fundación hecha por el Capitán José de Mendiola y su esposa, añadiendo:

\footnotetext{
40 Fol. 162v. La óptica de los fundadores no se reduce a los habitantes de la villa de Lequeitio, sino a cualquiera que desee aprender letras.

41 Fol. 163r.

42 Fol. 163v.
} 
«... para la Fundacion, y perpetuidad de la escuela de leer y escrivir y contar, y para los alimentos de un Religioso, que se ocupase en este Ministerio, adjudicaban, y adjudicaron los vecinos de dicha villa, para siempre jamás en cada un año, cien Ducados de Renta de las obras pías y Memorias que fundo el Contador Ochoa de Urquiza...»43

Los jesuitas admitieron ambas fundaciones.

Como vemos, los vecinos de la Villa de Lequeitio concedieron en perpetuidad 100 ducados de renta para el religioso que se ocupase del ministerio de la escuela de leer, escribir y contar.

Esta intención de la villa es tan importante que si faltase el dinero para el resto de las obras pías señaladas, la última en suprimirse fuese la escuela de escribir, leer y contar.

\section{Dotaciones económicas para misiones ${ }^{44}$}

\section{En la Iglesia de San Vicente de Arbacegui y su comarca}

Ha de durar ocho días consecutivos de 6 en 6 años, sin que sea intención del bienhechor coartar la libertad de los misioneros si creen oportuno alargar el tiempo de dichas misiones.

José de Basozabal, como testamentario de Pedro de Gamboa, el 16 de agosto de 1743, dota de 700 ducados en capitales de censos y 20 de renta al año, que se reparten de la siguiente manera:

300 ducados de vellón de principal y 8 de renta sobre la Puebla y vecinos de Mundaca. Una nota nos avisa que se acabó ese censo el 25 de octubre de 1743 .

200 ducados de principal y 6 de renta sobre las caserías de Ozollo y Ojangoytia, sus molinos y todas sus pertenencias en la anteiglesia de Gauteguiz de Arteaga, que se otorgaron el 10 de mayo de 1716.

100 ducados de principal y 3 de réditos sobre la casa y pertenencias de Agurrechea como principal, la de Solaguren Veazcoa, las de Portua y Arteaga, el 5 de enero de 1723.

100 ducados de principal y 3 de renta al año sobre las casas de Mumategui y Goxeazcoa y Naveran, Aurrecoechea principal y fiadora, y todas sus pertenencias en la anteiglesia de Gauteguiz, otorgada el 1 de marzo de 1724.

\footnotetext{
43 Fol. 165v. Nótese la curiosa identificación entre el Ayuntamiento de la villa y los vecinos de la misma, que utiliza este texto.

44 Téngase en cuenta que se trata aquí de misiones populares o predicaciones y prácticas religiosas que se tenían por algún tiempo en una determinada población. No tiene nada que ver con las misiones extranjeras.
} 


\section{En la villa de Larrabezua y su comarca}

José de Leguina, cura beneficiario de la Parroquia de Larrabezua, por escritura del 7 de mayo de 1752, fundó esta misión con la aprobación del ayuntamiento y aceptación de la Compañía de Jesús.

La predicarían los jesuitas del Colegio de Lequeitio.

Debía durar 15 días continuos cada 10 años.

La villa se encargaba del alojamiento.

\section{Dotación económica}

500 ducados de vellón para imposición a censo sobre fincas seguras o forma equivalente. Una nota nos avisa que tal imposición de 500 ducados no consta que existiera.

\section{En la Iglesia de Arrieta}

José de Recacoechea, presbítero beneficiado de la Iglesia parroquial de San Martín, de la anteiglesia de Livano de Arrieta, por escritura del 6 de julio de 1752, fundó otra misión.

Son del cargo del Colegio de jesuitas de Lequeitio.

Tiene que durar 12 días cada 8 años.

\section{Dotación económica}

700 ducados con obligación de imponerlos al censo sobre fincas seguras o equivalentes. Una nota nos avisa de que no consta de que hubo tal donación.

\section{Dotaciones económicas para misas}

Se dejaron 10.000 ducados por escritura ante Tomás de Gaceaga, escribano en Sevilla, para la fundación de misas por Juan de Zaracondegui, vecino de Sevilla, y su esposa, Leonor Alvarez de Lavandeira, en el Colegio de Lequeitio, por escritura del 19 de junio de 1738.

El arcediano de Sevilla, Gabriel Torres de Navarra, puso los $10.000 \mathrm{du}-$ cados de fundación en renta de 300 ducados anuales en escritura del 9 de agosto de 1738, con las siguientes hipotecas:

- Una hacienda de campo en la villa de Ginés.

- 40.034 reales y 5 maravedíes de vellón de principal, que eran parte de un tributo situado en el derecho de los Infantes, a nombre de Juan Martínez de Arriola y Lucía de Alzato. 
-4.000 ducados de principal sobre los arbitrios de la ciudad de Sevilla, «de parte en los 154.620 reales a nombre de don Pedro de Ocanto y Rivera» 45 .

-2.500 ducados de principal impuestos por don Luis González Torres de Navarra sobre una hacienda llamada de Gallo, en el término de la villa de Dos Hermanas.

\section{Obligaciones del Capellán del Colegio de Lequeitio}

El jesuita que se haga cargo de esta memoria, dotada de la forma indicada, tiene que procurar que se digan siete misas rezadas, tres de ellas los tres primeros días de la Pascua de Navidad, de Resurrección y Pentecostés.

Igualmente el día de la Inmaculada Concepción, de San Juan Bautista, del Patriarca San José, en la conmemoración de los fieles difuntos.

Cada una de estas misas está dotada de 15 reales de vellón, que los recibe el Colegio de la Compañía de Jesús, que se encarga del cumplimiento de la manda y de proporcionar el vino, cera y ornamentos necesarios para cumplirla.

El Patrono de esta fundación es el Rector del Colegio de Lequeitio.

\section{Conclusiones}

El Colegio de Lequeitio se funda con el propósito de abrir una escuela para enseñar a leer y escribir, una cátedra de gramática latina y, si fuera posible, otra de Teología Moral.

Por otro lado, también hay dotaciones para que los jesuitas del Colegio den tres misiones en S. Vicente de Arbacegui, en Larrabezua y en Arrieta.

También reciben mandas para misas.

\section{EL COLEGIO DE LOYOLA}

Archimbaud se apoya para darnos la información sobre la fundación del Colegio Real de Loyola en los documentos que existían en el Archivo del Colegio. En concreto, por lo que respecta al paso de la propiedad

\footnotetext{
45 Fols. 172r y v.
} 
de la casa torre nativa del Fundador de la Compañía de Jesús, S. Ignacio de Loyola, y el Colegio adjunto, se remite a la escritura pública que Juan Bautista de Landa, escribano público de la villa de Azcoitia, firmó el 1 de septiembre de 1767.

\section{A. Legado de los Marqueses de Alcañizas ${ }^{46}$ y de la Reina Mariana de Austria}

Según el citado documento:

«... en virtud de Real facultad expedida por el señor Rey Dn. Carlos segundo ${ }^{47}$ en Madrid en 14 de julio de 1681, los exc[elentisi]mos señores Dn. Luis Enrriquez de Cabrera y D ${ }^{\text {a }}$ Theresa Enrriquez de Velasco su muger, Marqueses de Alcañizas, y Oropesa, otorgaron escritura de venta, cesion, y traspaso en la Ciudad de Toro, en 7 de septiembre de 1681 ante Gabriel Gutierrez escrivano publico y del numero de dicha Ciudad: por la qual se desapropiaron del derecho y Patronato de la Cassa solar del glorioso Patriarcha san Ignacio de Loyola, y de su nacimiento, sita en jurisdicion de la villa de Azpeitia en la Provincia de Guipuzcoa, como poseedores, que eran del Mayorazgo, que fundò Martin Garcia de Oñaz, a favor del referido Patronato, en la Serenisima Reyna Madre Da Mariana de Austria ${ }^{48}$... en favor de la Religion de la Compañia, por 58.187 reales y medio en que fue valuado, con calidad de que dicha cantidad se huviese de imbertir por dichos señores Marqueses en la compra de otros Bienes, o renta perpetua en favor de dicho Mayorazgo...»49

Como compensación por esta cesión se ponían las siguientes condiciones:

- En la fachada de la Iglesia, debajo de las armas de su Majestad, en las paredes maestras de la Iglesia y claustros, que se pusiese una inscripción en mármol que manifestara cómo los Marqueses de Alcañizas hacían la cesión libre y voluntariamente.

- Con el nuevo edificio del colegio no se demoliese pared alguna de la torre por la venerable antigüedad de la misma.

46 En esta grafía aparece en el documento que utilizamos de Archimbaud. En el castellano moderno es: Alcañiz.

47 Carlos II el Hechizado. Rey de España y de Nápoles [Madrid, 1661-Madrid 1700]. Fue el último monarca de la Casa de Austria en España.

48 Reina de España [Viena 1634-Madrid 1696]. Desde 1665 desempeñó la regencia de su hijo Carlos II.

49 Fols. 224v, 225r, 225v. 
- Para los Marqueses se destinase una parte del edificio donde aposentarse cuando quisieran visitar la torre de S. Ignacio. Estos aposentos debían tener tribuna a la Iglesia para asistir con comodidad a los oficios divinos.

- Igualmente para dichos Marqueses, se fabricase en la Iglesia la mejor capilla para su enterramiento, con sus armas y las inscripciones antes citadas.

-Estas condiciones fueron aceptadas por el P. Manuel Rodríguez ${ }^{50}$, Rector entonces del Colegio de la Compañía de Villagarcía en nombre del P. Provincial ${ }^{51}$, el 7 de agosto de 1681.

-El 19 de febrero de 1682 Manuel de Arce y Astete, Corregidor de la Provincia de Guipúzcoa, tomó posesión en nombre de la Reina de la casa de Loyola y demás sitios.

—Dña. Mariana de Austria, en Buen Retiro el 24 de mayo de 1682, ante Isidro Angulo y Belasco:

«... hizo merced, gracia y donacion, pura, mera, perfecta, e irrebocable, de la expresada Cassa material de Loyola en favor de la Compañia de Jesus de la Provincia de Castilla, para que la conservase, e incorporase en el Colegio, que inmmediato a ella se havia de fabricar ...» 52

Exigía que el nuevo Colegio llevase la advocación de S. Ignacio de Loyola. Sería la misma Reina Mariana de Austria la Patrona durante su vida y después Carlos II, su hijo, y sus sucesores en la corona de Casti1la. No se podía enterrar a ninguna persona secular en el Colegio y Casa de Compañía sin su permiso o el de los Reyes de Castilla.

Cada dos años, perpetuamente, el día de S. Ignacio, el Rector del Colegio debía ofrecer un cirio de cera blanca con las armas reales del Colegio a S. Ignacio y el siguiente año, a la Fundadora, la Reina Mariana de Austria o, en su defecto, a sus sucesores en la Corona de Castilla.

Cuando falleciese dicha Reina Madre, hubiese en el Colegio una Misa con vigilia y responso, que se continuaría perpetuamente todos los años el día de los difuntos ${ }^{53}$.

50 Emmanuel Rodriguez [Valdefrancus, diocesis palentina 31.12.1633-el último catálogo de Castilla en que se encuentra su nombre es del año 1696].

51 Era el P. Johannes Nieto [Catalapiedra 19.10.1721 - † antes de 1700].

52 Fol. 228v.

53 Es curioso que al hacer esta manda, la Reina Madre se fija como modelo en el ejemplo del Colegio Imperial o Colegio de Nobles, como se le suele llamar y añade: «... como se hacia en el Colegio Imperial de la Compañia de Jesus de Madrid, por la Magestad Cesarea de la serenisima señora Maria de Austria [Mariana de Austria, Reina de España y Regente desde 
También el día de la Inmaculada Concepción, una misa cantada y lo mismo en la fiesta de S. José, por la intención de la Reina Madre.

La fundación fue aceptada por Mateo de Moya, Confesor de la Reina Madre, en nombre del P. Pascual Casanova ${ }^{54}$, Provincial de la Compañía de Jesús de la Provincia de Castilla la Vieja, que se comprometía a construir la Iglesia y el Colegio por escritura otorgada en Valladolid, el 25 de marzo de 1682 ante Gabriel Medina, escribano de número de dicha ciudad, habiendo precedido el permiso del P. General de la Compañía de Jesús, Charles de Noyelle ${ }^{55}$. Carlos II admitió en su patronato real esta fundación aprobando todo lo dispuesto en cédula real con fecha 23 de marzo de 1683.

La dotación económica era de 4.134.817 maravedíes de renta anual, que hacen 121.612 reales y 9 maravedíes.

\section{B. Legado de Ana de Lasalde, vecina de Azcoitia, viuda de Matías Ignacio de Zuazola Oñaz}

Además de la fundación de patronato real, el Colegio de Loyola recibió también otras donaciones.

El 3 de julio de 1688 ante Ignacio de Ernizqueta, escribano de número de la villa de Azcoitia, y por el codicilo del 20 de febrero de 1693:

«... declaró a este Colegio por heredero del remanente de todos su Bienes libres ...» ${ }^{56}$

- Una casería llamada Oyanguren en la jurisdicción de la villa de Azcoitia.

— La mitad de otra casería llamada de Cortazar en la misma jurisdicción.

- Una casería en el término de Larrascanda.

- Otra casería llamada de S. Juan, con sus pertenencias, heredades y montes, en la jurisdicción de la misma villa.

- Otra casería llamada de Aguirre, con su molino y demás pertenencias en la jurisdicción de la villa de Deva.

- Otra casería de Plazaola con todas sus pertenencias, en la jurisdicción de la villa de Deva.

- Otra casería de Ovieta con todas sus pertenencias, en la misma jurisdicción.

1665, Viena 1634-Madrid 1696], emperatriz de Romanos, Infanta de España, su Abuela y señora.» Fol. 232r.

54 Paschasius de Casanueva [Cádiz, marzo 1629 - † después de 1705 y antes de 1714]. Fue Provincial y Asistente de España.

55 Carolus Noyelle [Bruselas 1615-Roma 12.12.1686].

56 Fol. 235r. 
- Otra casería de Igarza con todas sus pertenencias, en la misma jurisdicción.

- Otra casería de Larrume, en la jurisdicción de la villa de Azcoitia.

- Tres casas de población en la villa de Azcoitia, en la calle Iparcalle.

- Una heredad junto a la casa de Floreaga.

—Un jaral sito junto a Olaverriaga.

\section{Obligaciones del Colegio}

Con toda la plata de Ana de Lasalde se hiciese una lámpara con sus armas dedicada a S. Ignacio, que ardiese perpetuamente en su capilla.

Dos religiosos del Colegio tenían que salir a dar misiones en la costa, especialmente en Deva, donde se debía de hacer cada 2 años.

Cuando se hiciese la misión en Zumaya, debían emplear dos días en Oiquina.

Se entregarán al P. Rector del Colegio 50 ducados de vellón, para que, con 500 reales de ellos, cada año se hiciese una alhaja necesaria o conveniente para el adorno de la capilla de S. Ignacio. Los 50 reales restantes quedaban también en disposición del P. Rector para su uso y disposición:

«... sin que este legado pudiese emplearse en gastos precisos de dicha Capilla, ni en otro ningun fin.» ${ }^{57}$

Además de esos 50 reales destinados anualmente al P. Rector del Colegio de Loyola, se le deben entregar otros 50:

«... por quanto dicho P. Rector, y sus succesores, debian ser los principales egecutores perpetuos de la ultima voluntad de la Testadora.» ${ }^{58}$

En su entierro pide la testadora Ana Lasalde que se diga, por su alma y la de sus difuntos en la Iglesia del Colegio, una Misa cantada con nocturno, responso y asistencia de la comunidad.

Todos los sacerdotes de la comunidad debían, ese día o los inmediatamente siguientes, decir una misa por su eterno descanso. Los no sacerdotes, un rosario.

Una misa rezada por la testadora todas las semanas.

\section{Legado de José Miguel de Ibarra, natural de la villa de Motrico}

El 12 de diciembre de 1736, Jose Miguel de Ibarra, ante Pedro Miguel de Urroz, escribano público:

57 Fol. 238v.

58 Fol. 239v. 
«... nombró a este R[ea]l Colegio de Loyola, por heredero de todos sus bienes libres ...» ${ }^{59}$

\section{Dotación económica}

- Concede al Colegio de Loyola la Casería Egusquiza, con todas sus pertenencias, en la jurisdicción de la villa de Motrico.

-Otra casería, Ipensacoa, con su huerta, en la misma villa.

- Otra casa contigua a la anterior.

- Otra casería por nombre Olazarcoa con huerta.

- La casería Domicusacoa con dos huertecitos y dos pedazos de tierra anejos a ella.

- 121 ducados en capital en ganado vacuno.

— La mitad del molino Marticoizena.

- Dos tierras y un manzanal llamadas Jaureguisoloa, en el término de Mijón.

\section{Obligaciones del Colegio}

Si se fundase en Motrico Colegio de la Companía, todos los bienes raíces habían de pasar a aquel colegio.

Desde 1750 el Colegio de Loyola debía pagar la subsistencia de un maestro de niños, nombrado por la villa de Motrico. Además del salario que le diese la villa, el Colegio le añadiría 34 ducados anuales perpetuamente «a fin de que se consiguiese por este medio la mejor enseñanza de los Niños» 60 .

\section{Legado de Pedro de Beristain, natural de la villa de Azpeitia}

En la ciudad de Méjico, el 4 de abril de 1720, ante Jacobo Gómez de Paradela, escribano público, otorgó Pedro de Beristain, natural y originario de la villa de Azpeitia y residente en dicha ciudad, los siguientes bienes al Colegio Real de Loyola.

\section{Dotación económica}

En dos ocasiones que se presentasen en aquellos reinos, enviaría en la primera 4.500 pesos y en la segunda 3.500 .

\footnotetext{
59 Fol. 240v.

60 Fol. 242r.
} 


\section{Obligaciones del Colegio}

Con 4.000 pesos de los 4.500 de la primera remesa, se fundase una capellanía de una misa por su alma todos los días de precepto en la Iglesia del Colegio de Loyola.

De los 500 pesos restantes de los 4.500 que venían en la primera remesa, se entregasen en la villa de Azpeitia a su madre, Magdalena de Oyarzabal, y, en su muerte, a su sucesor.

De los 3.500 pesos de la segunda remesa, se entregase a su madre, igualmente, 500. Si hubiese fallecido su madre, se emplease en dotar a una huérfana todos los años:

«... la qual hubiese de asistir el dia del Patriarcha san Ignacio en la Iglesia de dicha santa Cassa de Loyola, a Missa y sermon, vestida de Huerfana, cuyo nombramiento se hubiese de hacer en las Parientas del Fundador hasta el quinto grado y extinguida que fuese dicha linea, el P. Rector de ete Colegio, hechase suertes entre las Niñas Doncellas, hijas de toda la jurisdicion de Azpeitia ...» ${ }^{61}$

Estas disposiciones testamentarias fueron aprobadas por el P. Francisco Retz ${ }^{62}$, Prepósito General de la Compañía de Jesús el 14 de agosto de 1748 .

\section{E. Legado de Francisca de Merodio, madre del P. José Casani S.J.}

El P. José Casani 63 era testamentario de su madre, que fundó una memoria de misas en la Iglesia del Colegio de Loyola. anual.

Dejó un censo de 20.000 reales de renta principal y 600 de renta

\section{Obligaciones del Colegio}

La última misa de los días de fiesta:

«... siempre en la santa Capilla indispensablemente, para que sirva de alivio a los Indibiduos del Colegio y vecinos, pagando de limosna por cada una, seis R[eale]s de vellón.»64

\footnotetext{
61 Fol. 245v.

62 Franciscus Retz [Praga 1672-Roma 19.11.1750].

${ }_{63} \mathrm{El}$ testamento fue otorgado el 17 de julio de 1727.

${ }^{64}$ Fol. 249v.
} 
La misma obligación en 13 fiestas de santos de la Compañía de Jesús, pagando 4 reales de vellón, aplicándose por el alma de Francisca Merodio y Juan Bautista Casani, padres del jesuita José Casani.

\section{F. Legado de Magdalena Vázquez de Velasco, vecina de Potosí}

Magdalena Vazquez de Velasco, vecina de la villa imperial del Potosí, mandó a este Colegio de Loyola, ocho libras, ocho onzas y once adarmes de oro para instituir en la Iglesia del Colegio una Capellanía colativa, con la obligación de celebrar 80 misas rezadas anualmente y 36 en las 10 festividades de Nuestra Señora y de otros santos.

Es nombrado patrono de esta obra pía el Rector del Colegio de Loyola, P. Salvador de Ribadeo65. Cada misa se pagaba 8 reales de vellón. El capellán tenía que entregar al P. Rector que fuese de este Colegio tres ducados por razón del patronato y a la sacristía, 50 reales.

Archimbaud añade una nota diciendo que el Colegio no tiene ninguna carga por esta fundación, porque no posee los bienes de ella. Es el capellán quien debe pagar al Colegio, y no el Colegio al capellán.

\section{Conclusiones}

De los documentos aducidos se concluye que los Marqueses de Alcañiz eran los propietarios de la casa torre donde nació S. Ignacio. Por instigación de la Reina Madre Mariana de Austria, cedieron en ella estos derechos que ella, a su vez, pasó a la Compañía de Jesús.

La fundación fue aceptada por la Compañía de Jesús el 25 de marzo de 1682.

\section{EL COLEGIO DE OÑATE}

\section{Primera escritura}

Martín de Araoz Lazarraga, natural de la villa de Oñate, hizo testamento en Sevilla, con fecha 16 de mayo 1617, ante Juan Fernández de Ojeda, escribano público de dicha ciudad.

Deja por heredero de la mitad de sus bienes a su hermano Juan Araoz, «y la otra mitad de ellos, para la Fundación del Colegio de dicha villa de Oñate ...»66

\footnotetext{
65 Salvador de Ribadeo [Pasajes 31.7.1644 - † después de 1720 y antes de 1723].

66 Fol. 395v.
} 
En el testamento se expresa de la siguiente manera en lo que toca al Colegio de la Compañía de Jesús en Oñate, dice:

«... y de lo que montare la otra mitad restante de los dichos mis Bienes, es mi voluntad, que se funde en la dicha villa de Oñate, donde soy natural, un Colegio de la orden de la Compañia de Jesus por su gran Doctrina, y enseñanaza, é buen fruto, que de su mucha virtud se saca en qualquier parte, y lugar que están .... ${ }^{67}$

En caso de que las rentas no lleguen para la fundación del Colegio, deja encargados a las padres jesuitas Juan Vázquez, Valentín de Caravantes, Sebastián Delgado ${ }^{68}$ para que se distribuyan los bienes de Martín de Araoz Lazarraga en obras pías, por no tener el dicho fundador herederos ni ascendientes ni descendientes.

\section{Dotación económica}

Martín de Araoz, en la Ciudad de los Reyes del Perú, la cantidad de 33 pesos de a 8 reales de plata de las partidas siguientes:

—En la Caja de difuntos de la Ciudad de los Reyes de Perú, 24.000 pesos líquidos.

—En poder de Alonso Sánchez Chaparro 1.464 pesos.

- 7.000 pesos en Bartolomé de Larrea.

-500 pesos para gastos que surgieran de la Caja de Difuntos.

- 36 pesos de un cáliz nuevo, patena, copa dorada, vinajeras e incensario de plata.

\section{Obligaciones del Colegio}

La advocación del Colegio sería San Francisco de Borja, en cuya fiesta se haría misa cantada y sermón, aplicándose por el alma del fundador, Martín de Araoz, por la de su hermano y parientes fallecidos.

En ese día todos los sacerdotes residentes en el Colegio aplicarían la misa por la misma intención y los no sacerdotes, un rosario. Los jesuitas debían conseguir para esta fiesta un jubileo plenario. Cuando el P. General admitiese la fundación, que el fundador y sus familiares fueran tenidos

67 Fol. 396r.

68 En los catálogos de Castilla no encontramos ninguno de los nombres de estos tres jesuitas. Suponemos que al ser hecho el testamento en Sevilla, no pertenecerían a la Provincia de Castilla. 
como bienhechores, diciéndose en toda la Compañía tres misas rezadas por su eterno descanso y los no sacerdotes, tres rosarios. El día de S. Francisco de Borja, mientras viviera el fundador, Martín de Araoz, que se le dé la vela que se acostumbra dar en la Companía a sus fundadores.

Misas en las festividades de N. ${ }^{a}$ S. ${ }^{a}$ y de S. Juan Bautista por los fundadores. Pide entierro en la Iglesia del Colegio. Ha de tener el Colegio un Maestro de Gramática:

«... para los que quisiesen concurrir a la Aula, hasta que puedan salir buenos Gramaticos, y perfectos Retoricos, como también Religiosos, que lean de continuo una leccion de Theologia Moral, para el vien y utilidad de aquella villa.»69

En caso de que haya otros bienhechores que aporten algo a la fundación, nunca podrían suplantar a los fundadores en su carácter de patronos del Colegio, con todos sus privilegios.

No se puede trasladar el Colegio de Oñate a otra población, ni agregar las rentas a otros Colegios.

\section{Segunda escritura}

Es una aprobación y ratificación de la anterior escritura. La presente se otorgó en Sevilla el 28 de mayo de 1644, ante Miguel Burgos, escribano público de dicha ciudad. En ella:

«... efectivamente entregò de contàdo à los PP. Diego del Marmol ${ }^{70}$, Rector y Lucas de Inarra ${ }^{71}$ Procurador de la Provincia de Castilla 20.000 Ducados de vellón para la fundación de este Colegio ...» ${ }^{72}$

\section{Donación económica}

-20.000 ducados de sus bienes, como consta del recibo que otorgaron dichos padres.

-24.000 pesos de a 8 reales de plata que dejó en la Caja de Difuntos de la Ciudad de los Reyes.

69 Fol. 403v.

70 No aparece este nombre en los catálogos de la provincia de Castilla, creemos consecuentemente que no pertenecía a esta Provincia.

71 Lucas de Iñarra [Eibar 1609 - lo encontramos por última vez en el catálogo de la Provincia de Castilla de 1649].

72 Fol. 400v. 


\section{Obligaciones del Colegio}

Se amplían y concretan las de la primera escritura.

El Provincial de Castilla ${ }^{73}$, en el plazo de un año, debe traer la aprobación del General ${ }^{74}$, en caso contrario que se devuelvan los 20.000 ducados entregados para la fundación del Colegio.

Que se comience ya el colegio trayendo dos sacerdotes y dos hermanos para residir en Oñate «por via de misión, ó residencia» para los ministerios propios de la Compañía, la enseñanza de la gramática y la cátedra de teología moral.

De lo contrario, se les obligará a la restitución de los citados 20.000 ducados.

Para que los jesuitas no fueran gravosos a la villa, les adjudicaba 400 ducados anuales de los frutos y rentas de la fundación.

Los jesuitas aceptaron las condiciones propuestas.

\section{Testamento de Juan de Araoz}

En su testamento, Juan de Araoz, el 9 de mayo de 1671, ante Cristóbal de Soraluce, escribano de número de Oñate, donó nuevas partidas para el aumento de este Colegio.

\section{Donación económica}

-760 pesos que el P. Rector Gregorio de Medieta ${ }^{75}$ cobró efectivamente el 30 de mayo de 1649.

—6.000 reales de vellón que el mismo P. Rector percibió el 19 de junio de 1656.

— 400 ducados para emplearlos en censos.

-500 pesos que cedió al P. Rector Francisco de Recuerda ${ }^{76}$, para que los cobrase en el Reino del Perú.

73 En 1644 el Provincial de Castilla era el P. Johannes Antonius Velazquez [Avila 1586-la última vez que aparece su nombre en los catálogos de la Provincia de Castilla es en el año 1669].

74 Matias Vitellesci [Roma 1563-Roma 9.2.1645] era Prepósito General de la Compañía de Jesús en 1644.

75 Gregorio de Mendiola [Ceniceros 3.5.1613-murió entre 1679 y 1681]. Creemos que se trata de este padre jesuita porque aparece como Rector en esas fechas. Quizá Archimbaud leyó equivocadamente el nombre. No se encuentra en los catálogos de Castilla ningún P. Medieta, como dice Archimbaud.

76 Franciscus de Recuerda [Bilbao 4.10.1629-murió entre 1693 y 1696]. 
Obligaciones del Colegio

Los réditos de 400 ducados de capital a censo se empleasen en el mantenimiento de una lámpara de aceite para el alumbrado del Santísimo en la Iglesia del Colegio.

200 ducados, también del capital, para con los réditos anuales pagar la cera del Santísimo en la misma Iglesia.

200 ducados para construir la fachada de la Iglesia del Colegio.

Cuando se cobrasen los 500 pesos cedidos por el fundador en el Reino del Perú, se utilizasen también para cera del Santísimo y aceite de la lámpara de la Iglesia de este Colegio.

\section{La Compañía de Jesús y la villa de Oñate}

La predicación de los sermones vespertinos doctrinales de los cinco domingos de Cuaresma y la manutención de un maestro de primeras letras en el Colegio de la Compañía hizo surgir un pleito con el Ayuntamiento 77 y vecinos de la villa de Oñate y el Colegio de la Compañía de Jesús. El 9 de julio de 1765 se otorgó escritura de concordia ante Manuel de Iturmeneta, escribano de número de Oñate, en la que se comprometían ambas partes a lo siguiente.

Los jesuitas tienen que predicar siempre en la Iglesia Parroquial de Oñate dichos cinco sermones vespertinos los domingos de Cuaresma cada año.

El Colegio mantendrá un maestro de primeras letras para la enseñanza de la juventud. La villa contribuirá a la manutención de dicho maestro con la cantidad anual de 170 ducados de vellón, como lo había hecho hasta ahora.

\section{Conclusiones}

Las dotaciones económicas del Colegio de Oñate tienen unas exigencias modestas.

Provisionalmente se pide que haya a modo de misión dos padres y dos hermanos de la Compañía de Jesús.

En el campo de la docencia se exige un maestro de las primeras letras y una cátedra de moral.

La villa de Oñate se compromete a ayudar económicamente la manutención del maestro de primeras letras.

77 En época del documento se le llamaba: «cabildo secular». 


\section{EL COLEGIO DE ORDUÑA}

El Colegio de la Compañía de Jesús en la ciudad de Orduña se fundó, por escritura de fundación, el 8 de octubre de 1648 en la Ciudad de los Reyes por Juan Urdanegui, que era natural de Orduña.

La finalidad de la fundación del Colegio era la administración de los sacramentos, la enseñanza de las primeras letras, doctrina cristiana y latinidad a los niños y una cátedra de teología moral.

E1 nombre del Colegio sería de Jesús, María y José.

La situación de la nueva edificación será la más conveniente para que los vecinos de Orduña, hijos y familiares tengan buena doctrina y administración de los sacramentos.

Una vez que se acabe la construcción, debe albergar 14 jesuitas entre padres y hermanos.

\section{Obligaciones del Colegio}

Un jesuita se debe dedicar a ser maestro para los niños de la ciudad y la comarca, enseñándoles a leer, escribir y la doctrina cristiana.

Ha de haber otro maestro, también jesuita, que enseñe gramática y latinidad.

Se ha de mantener una cátedra de teología moral y casos de conciencia.

Los jesuitas deben dar misiones dos o tres veces al año, donde les destinase el P. Rector dentro de una distancia de tres o cuatro leguas de la ciudad.

La nueva Iglesia del Colegio ha de ser buena y sólida, con 5 altares y varias imágenes de santos.

\section{Dotación económica}

La dotación sería por una sola vez 40.000 ducados de a 8 colocados en la ciudad de Sevilla.

Un frontal de plata de peso de 84 marcos y tres onzas. Una custodia de plata sobredorada de peso de 5 marcos y una onza para la Iglesia del Colegio de la Compañía.

Si no tuviese efecto la fundación, se volviese a Juan de Urdaneta y su mujer Constanza de Lugan y Recalde los 40.000 reales de a ocho porque «cesando el fin deve volver el Capital a su tronco» ${ }^{78}$.

78 Fols. 419r y v. 
Juan de Urdaneta y Constanza de Lugan y Recalde tendrán el título de fundadores y se les enterrará a ambos a los lados de la parte alta del altar mayor.

Para todo ello se contaba con la aprobación del P. Juan Paulo Oliva ${ }^{79}$, como consta en la escritura.

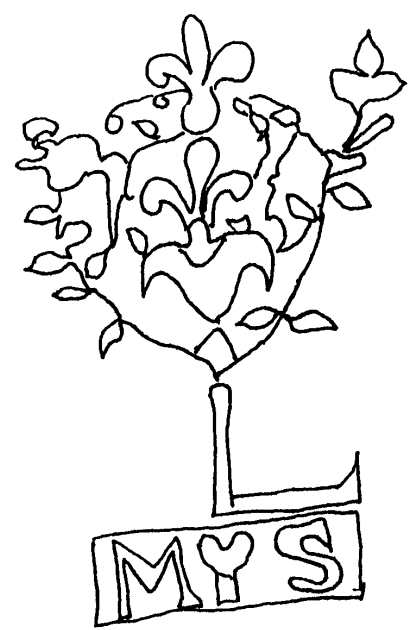

\section{CONCLUSIONES}

Hemos recogido y resumido los datos de Juan Antonio Archimbaud y Solano, Contador principal de las Temporalidades ocupadas a los jesuitas en noviembre de 1767 por orden de Carlos III, rey de España.

Ya hemos hecho notar al principio de este trabajo cómo no se trata de transcripción de documentos notariales originales, testamentos, mandas, donaciones, etc...., sino del estudio y resumen que hace de todas las temporalidades de los jesuitas el Contador principal, Juan Antonio Archimbaud.

En el caso del Colegio de Orduña el Archivo Histórico de Loyola nos ofrece otra posibilidad. Hemos encontrado citado a lo largo del trabajo con alguna frecuencia el Libro Becerro, que no parece ser otra cosa que el libro de cuentas del respectivo Colegio jesuítico.

En la cubierta de pergamino viene el título a tinta: N. ${ }^{\circ} 169$ Libro de Hazienda 1738. El folio primero que no está numerado lo encontramos

\footnotetext{
79 Johannes Paulus Oliva [Génova 1597-Roma 26.11.1681]. Prepósito General de la Compañía de Jesús.
} 
ya transcrito más abajo. En el Fol. 2r se contiene después de una «Notizia de la fundación deste Collegio» dos apartados subrayados: Juros y Zensos. En el mismo Fol. 2v otros dos apartados subrayados: «Prosiguen los censos» y «Hazienda raiz». A continuación transcribimos con la mayor fidelidad el folio numerado 1 que se titula: «Fundazion de este Collegio de la Comp ${ }^{a}$ de Jhs de la Ciudad de Orduña, por el señor General don Juan de Urdanegui.»

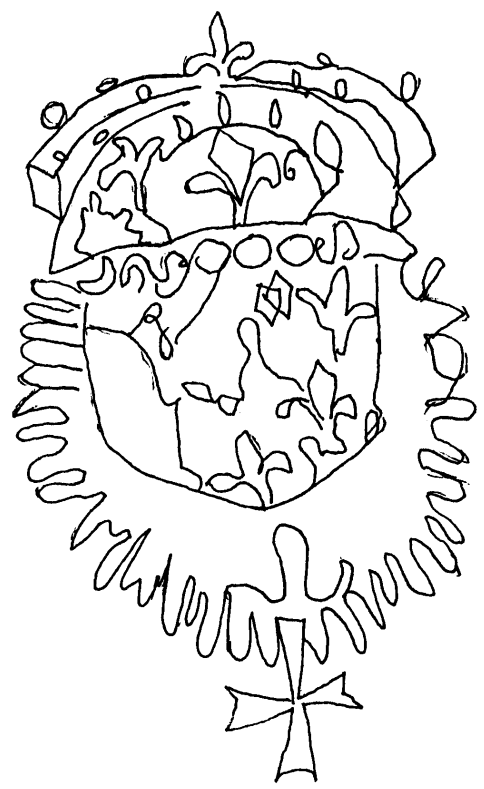

Sin embargo, tampoco ahora nos encontramos con un documento original como quizá podía esperarse. Es un escrito redactado por un jesuita anónimo, como consta de algunas expresiones que surgen a lo largo del mismo, por ejemplo en el Fol. 3r, en las dos últimas líneas, se habla de «nuestra calle» y en la última línea «nuestra casa»80. En el Fol. 6r: «en virtud de la horden de $N\left[\right.$ uestro] P. General» ${ }^{81}$.

Además de este libro y escrito que hemos transcrito fielmente a continuación, hay en el Archivo Histórico de Loyola otro documento muy similar.

\footnotetext{
80 El subrayado es nuestro
}

81 El subrayado es nuestro. 


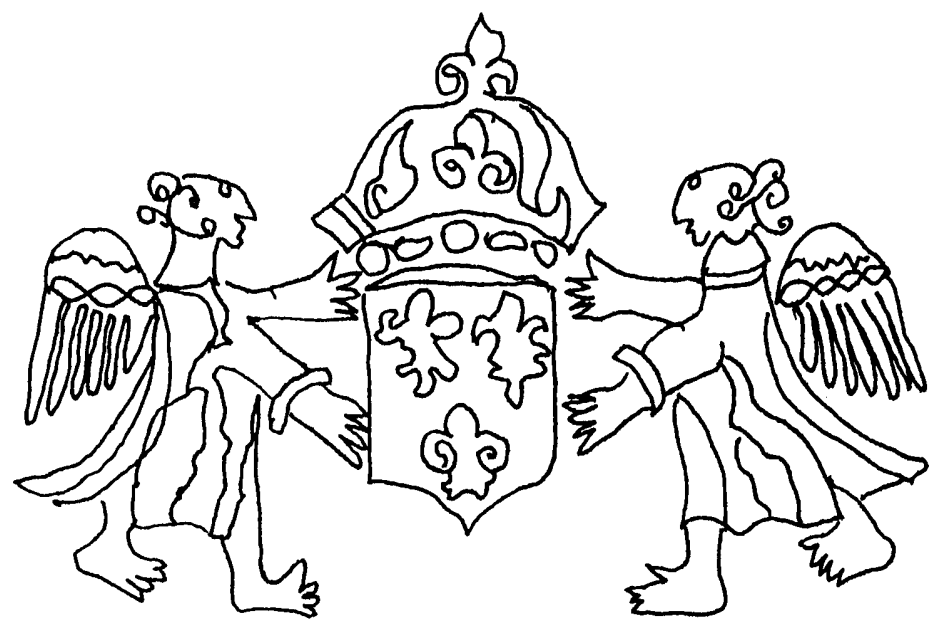

Comienza este documento que llamaremos D2 con un índice, cuyos epígrafes son: Fundación, Juros, Razón de las alhajas depositadas, Rectorados, Censos, Empleos, Librería, Libros que se compran, etc...

Inmediatamente después del índice se inicia un texto que no tiene paginación numerada. Lleva el título: «Razon de la fundacion de este colegio de la Ciudad de Orduña».

En cuanto al resto de las variantes las señalaremos a lo largo del escrito del Libro Becerro, que transcribimos inmediatamente.

$+$

[Fol. 1r] Libro de Vezerro de este Collegio de la Compa de Jhs de la Ciudad de Orduña, formado por el mes de Henero de el año de 1738. =.

[Fol. 1v en blanco]

[Fol. 2r] Indice de lo expresado en este Libro

[Fol. 2v] Prosiguen los zensos $=$

[Fol. numerado 1] 
Fundazion de este Collegio de la Compa de Jhs de la Ciudad de Orduña por el señor General Dn.

\section{Juan de Urdanegui.}

El Sor General D 82 Juan de Urdanegui natural de esta ${ }^{83}$ ciudad $^{84} \&$ vezino de la Ciudad de los reyes en ${ }^{85}$ reyno del Peru fundò este Collegio $^{86}$ De la Compa ${ }^{87}$ de Jhs con ${ }^{88}$ titulo y nombre de Jesus, Maria y Joseph $^{89}$, hauiendose otorgado para ello es[critu ${ }^{\text {ra }}$ entre el Pe Juan de Elizondo ${ }^{90}$ por de el Collegio de Biluao poder hauiente del Pe Prov[incia]', y el Liz[encia] ${ }^{\text {do }} \mathrm{D}^{\mathrm{n}}$ Franz[is] ${ }^{\text {co }}$ Ortiz de Zarate y de Bernaue de Urdanegui poder hauientes de d[ich]o Sor General, a 7 de Abril de 1677 por ante Juan Bap[tis] ta elorduy S[cretar] ${ }^{\text {rio }}$ de el numero desta Ciudad. Dio para d[ic]ha ${ }^{91}$ fundazion quarenta mil R[eal $]^{\text {es }}$ de $\hat{a}$ ocho ${ }^{92}$ para con sus reditos comprar sitio, $\mathrm{y}^{93}$ edificar Yglestia, y Colle ${ }^{94} \mathrm{y}^{95}$ en el interin que no se acauasen perfectam[en $]^{\text {te }}$ quiso que no auitase religioso alguno para por este medio lograr el que se efectuasen con mayor vreuedad, y que concluido con la fabrica de $\mathrm{d}[\mathrm{ich}] \mathrm{a} \operatorname{Ig}[\mathrm{lesi}]^{\mathrm{a}}$ y Collegio hubiese Catorce sujetos entre Padres y Hermanos ${ }^{96} \hat{o}$ los que pareziese al Pe Prov[incia] ${ }^{197}$.

Puso $\mathrm{p}[\mathrm{o}]^{\mathrm{r}}$ condizion que aya de hauer escuela de Leer, y escriuir, siendo ${ }^{98}$ el $\mathrm{m}$ [aest]ro religioso de $1 \mathrm{a}^{99}$ Comp ${ }^{100}$ como tambien un $\mathrm{m}$ [aestr]ro que Lea Gramatica y Latinidad, y otro que Lea theologia mo-

82 D2: «Don».

83 D2: «muy noble».

84 D2: «de Orduña»

85 D2: «el».

86 D2: «collo».

87 D2: «Compañia».

88 D2: «el».

89 D2 omite todo el párrafo desde: «hauiendose ... hasta: dicha Ciudad.»

90 Johannes de Elizondo [Irurita 10.3.1612-murió en Loyola entre 1690 y 1693].

91 D2 omite: «dicha».

92 D2 sustituye la frase siguiente desde: para ... comprar por el texto siguiente: «los quales mando que se pusiesen en renta fixa, y que de los reditos que se cobrasen se comprase».

93 D2 en lugar de «y edificar» escribe: «en el qual se edificase».

${ }_{94} \mathrm{D} 2$ en lugar de la palaba «collo», pone vivienda.

95 D2 en lugar de las frases contenidas entre: «en el interin ... de d[ic]ha $\operatorname{Ig}[$ lesi]a» tiene el siguiente párrafo: «que con los mismos reditos se hiciesen el edificio de la Iglesia y colegio y que asta que estuuiesen perfectamente acauados Uno y otro no se pusiesen ni hauitasen religiosos, para que asi mas en breve se acauasen y que despues de auerse acauado La».

96 D2: «Herm[an]os».

97 D2: «Prouincial».

98 D2 en lugar de «siendo el m[aes]tro», dice: «y que el maestro aya de ser».

99 D2: «misma compañia».

100 D2 en lugar del párrafo: «como tambien ... y Casos de Conzienzia» tiene el texto siguiente: «= que aya de auer Un maestro q[ue] Lea Gramatica y Latinidad = que aya de auer Un maestro que lea theulugia moral y casos de conciencia». 
ral \& Casos de Conzienzia, y que los demas religiosos ayan de asistir â confesar, Predicar, y a los demas ministerios que exercita ${ }^{101}$ la Compa .

Que dos, ô tres vezes al año â eleccion de el Pe R[ect]or este Collegio ande salir a missiones en distanzias de tres, ô, quatro Leguas desta Ciudad, queriendo ${ }^{102}$ que esto se tenga espezial atencion con el Valle de Gorejuela, por estar sita en el, la torre y Casa ${ }^{103}$ Solar de Urdanegui ${ }^{104}$ orignaria suya.

Que la Ig[lesi $]^{\text {a }}$ se fabricase ${ }^{105}$ de buena, y aseada Arquitectura y que aya de ${ }^{106}$ hauer Cinco Altares. Que en el primer Cuerpo Del [Fol. no numerado $2 \mathrm{v}$ ] retablo ${ }^{107}$ mayor se pongan (como lo están) ${ }^{108}$ tres $^{109}$ bultos de Cuerpo. Uno de nuestro $S^{r}$ en su Infanzia, otro de Nuestra Señora, y otro de San Joseph.

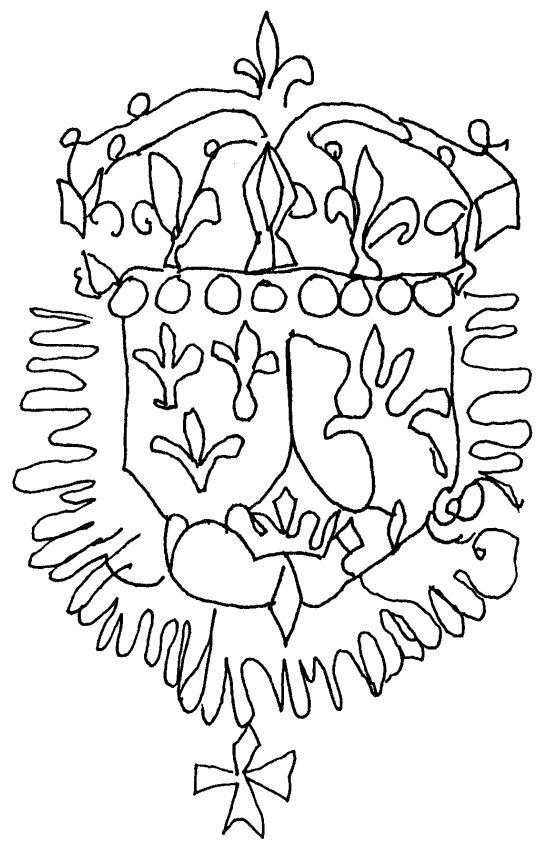

101 D2: «executa».

102 D2: «y quiere».

103 D2 omite: «Casa».

104 D2 añade: «que es».

105 D2 en lugar de: «Que la Igl[esi]a ... fabricase», dice: «que se ha de fabricar Una Iglesia».

106 D2 en lugar de «y que aya de» escribe: «en que ha de».

107 D2 añade: «del altar».

108 D2 omite este paréntesis.

109 D2 añade: «hechuras de Vulto» y omite: «bultos de cuerpo». 
Que asi â d[ic]ho110 Sor fundador como $\hat{a}^{111}$ su señora esposa 112 $\mathrm{D}$ [oñ]a Costanza de Luxar y recalde ${ }^{113}$ se les de el título onores, y honras de fundadores deste collegio ê ${ }^{114}$ Ig[lesi] ${ }^{a}$ y lo mismo â sus Hijos, y le[giti]mos descendientes en la forma regular que en los mayorazgos de España, y ayan de ser Patronos unicos perpetuos de $d$ [ich]a fundazion, y cada uno en su tiempo a de gozar de todas las preeminencias, sufragios y prerrogativas que la Compa aze â sus fundadores.

Que mientras d[ic]hos fundadores, $\mathrm{y}^{115}$ sus hijos y descendientes estubieren ausentes aya de gozar, y goze en $\mathrm{d}[\mathrm{ic}]$ ho Collo todos los onores y priuilegios de tal Patrono, el Sor Bernaue de Urdanegui primo del $\mathrm{S}^{\mathrm{r}} 116$ $\mathrm{D}^{\mathrm{n}}$ Juan $^{117}$ como dueño y S[eño] ${ }^{\mathrm{1} 18} \mathrm{p}[\mathrm{o}] \mathrm{r}$ hijo ${ }^{119}$ Hermano mayor, y después de ${ }^{120}$ sus dias los duenos, y señores q[ue] fueren de la di[c]ha torre $^{121}$ y solar de Urdanegui.

Que en los dos lados de el retablo mayor y sobre la puerta principal de la Iglesia, se an de poner en sus escudos las Armas de los Señores fundadores.

Que el d[ic]ho Sor General y la $S^{\text {ra }} D^{\text {a }}$ Costanza su muger se puedan enterrar en el presuiterio de la Capilla mayor, y que puedan hazer uno ô dos Nichos a los dos lados en parte alta para que se pongan sus bultos y un letrero con letras de Oro. Y que los demas patronos que por tiempo fueren, sus Hijos, y descendientes varones y hembras se puedan enterrar en el cuerpo de la Capilla mayor dejando libres los dos lados colaterales de la $\mathrm{d}[\mathrm{ic}] \mathrm{ha}$ Capilla mayor para que se entierren los religiosos de ${ }^{122}$ este Colle[gi $]^{\circ}$ como todo lo referido consta de la d[ic]ha es[critu] ${ }^{\text {ra }}$, cuya Copia se allara en el Nicho $1^{\circ}$ de el Archiuo num[er] 1 .

${ }^{123} \mathrm{En}^{124} 18$ de oct[ub] ${ }^{\text {re }}$ de 1678 ante Bentura de Garay S[ecreta] ${ }^{\text {rio }}$ de el num[er] ${ }^{\circ}$ desta Ciudad se otorgò es[critu] ${ }^{\text {ra }}$ (cuya copia se alla con la de

110 D2 en lugar de: «Que asi ... d [ich]o» dice: «quiere asi mismo el».

111 D2 en lugar de «como» dice: «que».

112 D2 en lugar de: «esposa» vuelve a repetir: «y a la señora».

113 D2 omite desde: «recalde ... y honrras».

114 D2 omite todo este párrafo: «ê Ig[lesi]a y lo mismo ... la Compa aze â sus fundadores.»

115 D2 añade: «el Señor General Don Juan de Urdanegui y La Señora Doña Constanza de Luxan Recalde su muger, o».

116 D2 añade: «General».

117 D2 añade: «de Urdanegui».

118 D2 sustituye: «p[or]» con la frase: «que es el d[ich]o S[eñ]or Bernaue de la torre, casa y solar de Urdanegui por».

119 D2 añade: «de».

120 D2 sustituye: «sus dias los dueños ... que fueren» por: «los dias del d[ich]o Señor Bernaue de Urdanegui han de suceder en el d[ic]ho Patronato los demas señores y dueños que fueren».

121 D2 añade: «casa».

122 D2 en lugar de las frases: «este Collo ...Archivo num ${ }^{\circ}$ 1.» concluye el párrafo con las palabras: «de la Compa»».

123 (Al margen) Capitulaciones con la Ciudad y cauildo.

124 D2 tiene distinta redaccción en todo este párrafo. No tiene la nota marginal. Todo lo comprendido ente estas dos frases: «En 18 de Oct[ub]re ... Continenen los capitulos siguientes =», se redacta así en D2: «Estas son las condiciones y grauamenes que los d[ich]os Seño- 
arriua) entre abmos cauildos, ecc[lesiasti]co y secular, y el Pe Pedro Geronimo de Cordoua Prov[incia $]^{1}$ desta Prov[inci] ${ }^{a}$ de Castilla, la qual contiene los Capitulos siguientes $=$

$1 \mathrm{Lo}^{125}$ primero que reconociendo el Pe Prov[incia] ${ }^{1}$, la cortedad de los te[rmi $]^{\text {nos }}$ de esta Ciudad, y que el comprar hacienda raiz, y de campo mas de lo preciso ${ }^{126}$ y Casa, Huerta y granxa seria en perjuicio de los vezinos de d[ic]ha Ciudad y de el Valle de Arrataria se obligo y obliga al ${ }^{127}$ Collegio que en ningun tiempo compraria, ni tendria hazienda alguna de campo, sease de pan llevar, 1[egiti]mas ${ }^{128}$, casas, Huertas, molinos, ruedas, montes ni fruto, ni usufruto dellas ni censos de qualquiera calidad que sean asi en esta Ciudad como ni en su jurisdizion ni en el d[ic]ho Valle de Arrastaria. Y que si por tiempo lo adquiriese por Donazion inter uibos ô causa mortis, ô, por legado en testamento, ô por lex[iti]ma, o renunzia de alguno de $\operatorname{los}^{129}$ religiosos obligo el Pe Prov[invia ${ }^{1}$ al Collegio a que se desara della dentro de un año vendiendola segun los fueros de este señorio, y costumbre de esta Ciudad. Y que solo podra tener el $\mathrm{d}[\mathrm{ic}]$ ho Collegio cinquenta Avanzadas de tierra para una Huerta domestica, y doscientas para una casa de recreazion. Podra tener juros en esta Aduana $=$

2 It[em] que no pueda el Collegio pedir limosna en esta Ciudad, y en quatro leguas en contorno, pero pueden los que hizieren la Profesion pedir limosna los tres dias antes de hazerla como lo usa la Compa segun sus constituziones $=$

3 It[em] que este Collegio aya de guardar las ordenanzas desta Ciudad como las guardan y obseruan los combentos de San Fran[cis] ${ }^{\mathrm{co}}$ y S.ta Clara, como es no tener carnizeria, ni tauerna ${ }^{130}$, pero puede el Collegio com$\operatorname{prar}^{131}$ todo lo nezesario para su Consumo sin oblig[aci] on de pesarlo en el peso pu[blic $]^{\mathrm{o}} 132 \mathrm{ni}$ dar quenta de ello al ayuntam[ien $]^{\text {to }}$. Puede asi mismo tener el Collegio sus ganados en los pastos comunes y propios desta Ciudad como los demas vezinos de ella, y gozar de todas las franquezas menos las que queden ezeptuadas ${ }^{133}$.

res Fundadores ponen al colegio, como consta por la escritura que se otorgo ante Bentura de Garay en esta Ciu[da]d de Orduña a 18 de octubre de 1678 años. Por esta misma escriptura consta de los capitulos entre los dos Capitulos secular y eclesiastico y La Comparlia asistiendo al otorgamiento de ella el P. Pedro Geronimo de Cordoua Prou[incia]l de esta prouincia de castilla.»

125 D2 dice: «El».

126 D2 añade después de la palabra: «precisa» las palabras: «para el edificio de la Iglesia».

127 D2 añade: «dicho».

128 D2 en lugar de: «legítimas», dice: «viñas».

129 D2 dice: «sus».

130 D2 añade: «para vender».

131 D2 en lugar del texto: «comprar todo ... para su consumo» escribe: «para su consumo comprar lo necesario».

132 D2 añade: «de esta Ciudad».

133 D2 dice: «exceptuadas». 
4 It[em] que este Collegio aya de pagar diezmos y Primizias De qualesquiera frutos que cojiere, menos de $\mathrm{e}^{134}$ el ganado, Huertas y Casa de Campo.

5 It[em] que los criados de el Collegio que uiuen dentro de el, puedan enterrarse en su $\operatorname{Ig}[\text { lesi }]^{a}$ sin obligazion de pagar derechos a las Parroquias, y en este caso no tienen los Curas y venefiziados [Fol. numerado 2v] obligazion de hazer los ofizios y funerales. Que si el Patron, su muger y sus Hijos, se enterrazen en la Igl[esi] ${ }^{a}$ deste Collegio no se ayan de pagar derechos por lleuar el Cuerpo, sino los derechos de los ofizios, y funerales como se pagan en la Parroquia, y si alguno otro se enterrase que aya de pagar al Cauildo cien duca[do] ${ }^{\text {s }}$ por el acompañamiento y demas ${ }^{135}$ derechos de ${ }^{136}$ funerales, $\mathrm{y}^{137}$ de los ofizios.

$6 \mathrm{It}[\mathrm{em}]$ que ninguno pueda enterrarse en nuestra $\operatorname{Ig}[\mathrm{lesi}]^{\mathrm{a}}$ sin que prezeda Lizenzia de su $\mathrm{Pe}$ General, ô de el Pe Prov[incia] ${ }^{1}$ que la tubiere $\mathrm{p}$ [o]r comu[nicaci] ${ }^{\text {on }}$ y en caso que no hubiere tiempo para pedir $\mathrm{d}[\mathrm{ic}]$ ha Liz[enci] ${ }^{\mathrm{a}}$ podra enterrarse con la presunta ${ }^{138}$ que si el $\mathrm{Pe}$ $\mathrm{R}[\mathrm{ect}]^{o r}$ presumiere que en tal caso daria Liz[enci] ${ }^{\mathrm{a}}$ el Pe General, ô el Prov[incia $]^{1}$.

7 It[em] que el Cauildo pueda entrar con su Cruz Parroquial personalmente asta el Altar mayor quando lleuase los cuerpos a la $\operatorname{Ig}[1 \text { lesi] }]^{\text {a }}$ de el Collegio para enterrarse, pero en $\mathrm{d}[\mathrm{ic}]$ ha $\operatorname{Ig}[\mathrm{lesi}]^{\mathrm{a}}$ no puede hazer funzion alguna y si la quisiere hazer como es cantar misa de cuerpo presente, cantar noturno, hazer ofizio de Sepultura, a de proceder Lizenzia de el $\mathrm{Pe} \mathrm{R}[\mathrm{ect}]^{\text {or }} \mathrm{y}$ si en nuestra Iglesia concurrieren las Cruzes de la Parroquia, y Collegio, a de prezeder la de el Collegio como en Casa y territorio propio.

$8 \mathrm{It}[\mathrm{em}]$ que en ningun tiempo aya de rezeuir el Collegio Limosna ni estipendio $\mathrm{p}[\mathrm{o}] \mathrm{r}$ misas, ni entierros.

9 It $[\mathrm{em}]$ que este Collegio aya de predicar en cada un año catorze sermones en las dos Parroquias de Santa María y San Juan. Otros catorze sermones predica ${ }^{139}$ el Comb[en] to de San franz[is] ${ }^{\text {co }}$ alternatiuam[en $]^{\text {te }}$ segun la tabla, sin que $\mathrm{p}$ [or] esto pueda lleuar el Collegio estipendio alguno.

$10 \mathrm{It}[\mathrm{em}]$ que en las Prozesiones de la semana santa y vispera de la Ascension aya de rezeuir el Collegio al Cauildo secular, y ecc[lesiasti]co que ban prozesionalm[en $]^{\text {te }}$ unidos como lo haze el Combento de San franz $[\text { is }]^{\mathrm{co}}=$

134 D2 en lugar del texto: «de el ganado ... de Campo», escribe: «de los que cogiere en su huerta y casa de campo, y ni tampoco del ganado que tuuiere y criare para su sustento».

135 D2 añade: «de esos».

136 D2 añade: «los».

137 D2 omite: «y».

138 D2: «presumpta».

139 D2 en lugar de: «predica» dice: «ha de predicar». 
$11{ }^{140}$ Zerradas estas Capitulaziones (aunque no estan firmadas de n[uest]ro Pe Gen[era] ${ }^{141}$ tomo la posesion el Pe Prov[incia] ${ }^{141}$ bis con asistenzia de ambos Cauildos ${ }^{142}$ â son de campana en la Casa que estaua en la Calle que llamau[a] ${ }^{n}$ de al medio vajando $\mathrm{p}[\mathrm{o}$ ]r la plaza â [Fol. numerado 3r] mano derecha ${ }^{143}$ pegante $^{144} \mathrm{p}[\mathrm{o}] \mathrm{r}$ la parte de arriua al solar ${ }^{145}$ de la Casa de Dn Alvaro de Ruiaguda ${ }^{146}$.

$12{ }^{147}$ En virtud de lo referido ${ }^{148}$ el Pe Prov[incia] ${ }^{1}$ embio a los Pes 149 Ant[oni] ${ }^{\circ}$ Casaues y Pedro Miranda para que diesen prinzipio a los ministerios de predicar, confesar y asistir a los enfermos ${ }^{150}$. Llegaron los Pes con el $\mathrm{H}[\text { erman }]^{\circ}$ Bartholome de Baluerde, y tubieron por ${ }^{151}$ morada la $\mathrm{d}[\mathrm{ic}]$ ha casa. Dieron prinzipio a los ministerios con una mision que la hicieron en esta Ciudad con grande fruto espiritual de todos sus auitadores, y continuaron con el mismo fruto ${ }^{152}$ los empleos de la Compa ${ }^{153}$ siendo consuelo de los mas desualidos enfermos a quienes asistian infatigables con la direcc[i] ${ }^{\text {on }}$ para sus almas, y con las limosnas que les dauan que fueron continuas, y muy nezesarias para las graues nezesidades ocasionadas de los temporales que eran ${ }^{154}$ calamitosos, y las enfermedades muchas. Hazian los Pes muy continuas platicas en la plaza explicando la Doctrina christiana a los niños. Dauan en la puerta de Casa Limosna todos los dias a todos los pobres que llegauan, y enseñauan a los niños las oraziones. Por ser la casa muy ${ }^{155}$ estrecha ${ }^{156}$ y no poderse hazer en esta $\operatorname{Ig}[\text { lesi }]^{a}$, ô oratorio iban $\operatorname{los} \mathrm{P}^{\mathrm{es}}$ a la Ig[lesi] a de Santa Maria, en la qual estuan oyendo las Confesiones de los que llegauan. Estos fueron los ministerios en que se ejercitaron los Pes, desde 20 de Nov[iembr] de 1678 en

140 (Al margen) Posession de el Collegio.

141 D2 en lugar del párrafo: «Zerradas estas ... de Nuestro Padre General», dice: «Aquí se acauaron las condiciones y se cerraron las escripturas y Luego».

141 bis Parece ser Gerónimo de Córdoba. Véase más abajo nota n. ${ }^{\circ} 168$.

142 D2 en lugar del texto: «a son de campana ... de Cal medio» escribe: «en la casa que esta en la calle que llaman cal del medio».

143 D2 añade: «y para esta parte de arriua esta».

144 D2 omite aquí: «por la parte de arriua».

145 D2 en lugar del texto: «de la casa» dice: «que es».

146 D2 añade: «aqui se tomo la posesion a son Campana tañida». Al margen también se añade el texto: «No estan firmados p[o]r N[uestro] P[adr]e Gen[era]l estos 14 capítulos ô Cond[icion]es».

147 (Al margen) Primeros P[adr]es.

148 D2 omite: «En virtud de lo referido».

149 D2 en lugar de: «a los Padres ... de Miranda» dice: «al P[adr]e Antonio Casaues y al P[adr]e Pedro de]».

150 D2 añade: «y ayudar a morir».

151 D2 en lugar de: «por» pone «de».

152 D2 omite: «con el mismo fruto».

153 D2 sustituye la palabra: «siendo» por el texto: «con el mesmo fruto y».

154 D2 añade aquí: «muy».

155 D2 en lugar de: «muy» dice: «tan».

156 D2 en lugar de la frase: «y no poderse ... ô oratorio» dice: «que no se pudo poner oratorio o Iglesia publica». 
q[ue] llegaron, asta 25 de Julio de 1679, en que se fueron el Pe Antonio Casaueo al Collegio de Obiedo, y el Pe Pedro Miranda al de Areualo ambos Pes Rectores.

$13{ }^{157} \mathrm{~A}$ estos ${ }^{158}$ Pes suzedieron en esta casa de fundazion el Pe Mar[ti]n de Lazcano, y el Pe Pedro de Arana que llegaron â 22159 de Julio de d[ic]ho año de 1679 y continuaron el empleo de sus ministerios.

${ }^{160}$ Este año que fue el Primero se hizo la fiesta de Nuestro Pe S[a] ${ }^{n}$ $\operatorname{Ig}[\text { naci }]^{\circ}$ en el Domingo de su Infraoctaua por razon de q[ue] el dia de el Santo ${ }^{161}$ siendo de trauajo podrian asistir pocos y mas siendo tiempo de siega y trilla. El sauado Vispera de la Celebridad hubo ogueras en nuestra Calle $\mathrm{y}^{162}$ pusieron luminarias en las ventanas de nuestra casa, y [Fol. numerado 3v] y (sic) ${ }^{163}$ en algunas de la vecindad. Hubo mogiganga muy graziosa que siruio de regocijo â toda la Ciudad, y todos los De ella mostraron con publicas demostraciones de aluorozo el contentami[en] ${ }^{\text {to }}$ con que mirauan lo que nunca pensaron ver, y asi dauan todos los cavalleros y sacerdotes las norabuenas a los Pes. El Domingo se zelebro la festiuidad de el Santo con el concurso de toda la Ciudad asistiendo ambos Cauildos plenos. La misa se canto con la mayor solemnidad que se pudo. Hubo sermon el qual predico el Pe Mart[i]n de Lazcano a que asistio el Pe Guardian de San franz[is]co con toda su Comunidad. Todo se hizo en la $\operatorname{Ig}\left[\right.$ lesi] ${ }^{\text {a }}$ de Santa Maria Domingo 6 de Ag[ost] ${ }^{\circ}$ del d[ic]ho año de $1679=$

14 Los ministerios de Confesar y asistir a los moribundos se continuo con azeptazion de toda la Ciudad, que no acauaba de dar grazias â Dios $\mathrm{p}[\mathrm{o}]^{\mathrm{r}}$ la frequenzia de Sacram[en ${ }^{\text {tos }}$ que se veya. Hazianse estas Doctrinas de los Domingos por las Calles con los niños de la escuela pero luego se allegauan los mas de los S[eño] ${ }^{\text {res }}$ Sazerdotes y caualleros, y ciudadanos que iban cantando en alta voz, exemplo no visto en los Collegios de Castilla. Rematauan estas doctrinas en la Ig[lesi $]^{\text {a }}$ de San Juan a que acudian las señoras y demas mugeres â oyr la explicazion de la doctrina christiana y la platica despues voluian todas cantando a la $\operatorname{Ig}\left[\operatorname{lesi}{ }^{\mathrm{a}}\right.$ de $\mathrm{S}[\mathrm{ant}]^{\mathrm{a}}$ $\mathrm{M}\left[\operatorname{arí}^{\mathrm{a}}\right.$.

15 La Quaresma de 1680 se explicaua en todos los sermones que se predicuan en Santa M[is ${ }^{a}$ los domingos p[o] $]^{\mathrm{r}}$ la mañana, y en $\mathrm{S}^{\mathrm{n}}$ Juan $\mathrm{p}[\mathrm{o}]^{\mathrm{r}}$ la tarde la doctrina christina, y se publico el Jubileo de las Doctrinas, y el de la Comunion General: esta se hizo el dia de la Anunziazion con extraordinario concurso de confesiones, gastaronse aquel dia sobre

157 (Al margen) Segundos P[adr]es.

158 D2 en lugar de: «estos» dice: «los».

159 D2 dice «24».

160 (Al margen) $1^{\text {a }}$ fiesta de N[uestro] S. Pe en la Parroquia.

161 D2 en lugar del párrafo: «siendo de trauajo ... de siega y trilla» dice: «Siendo de travaxo acusan de ser pocos los que pudiesen asistir a la fiesta y particularmente siendo aquel tiempo el de la siega y la trilla.»

162 D2 añade: «se».

163 D2 solamente usa una conjunción «y». 
nuebezientas formas. Se siguio a lo referido la Doctrina General el domingo siguiente con numero de jente jamas visto ${ }^{164}$. Salio de $\mathrm{s}^{\text {ta }}$ Maria muy hordenados en Ylera, todos iban cantando de dos en dos los Sres sazerdotes y algunos caualleros. el Cauildo ecc[lesiasti]co remataua con manteos y vonetes. el Sor Alcalde y Sres rex[idor]es cerrauan las Yleras, y despues se seguian las señoras ${ }^{165}$, y a su exemplo todas las mug[er]es de la Ciudad, y de los lug[ar]es vezinos en grandissimo numero. Voluiendo la Doctrina a la $\operatorname{Ig}\left[\right.$ lesi] a de $\mathrm{S}^{\text {ta }}$ [Fol. numerado 5r] Maria, ${ }^{166}$ y se remato tan glorioso empleo con explicar la Doctrina christiana y platica $=$

${ }^{167}$ El Pe Prov[incia] ${ }^{1}$ Pedro Geronimo de Cordoua ${ }^{168}$ vino â esta ciudad en ${ }^{169} 17$ de $^{170}$ Abril de 1680 â $^{171}$ hazer elecc[i] ${ }^{\text {on }}$ de $^{172}$ sitio para la Ig[lesi] ${ }^{a}$ y Collegio. Hizola en la plaza desde la esquina de la calle de Burgos asta la casa de Dn Mart[i]n de Barona inclusiue: esto es la calle auajo, ${ }^{173}$ asta el tope con las casas de $\mathrm{D}^{\mathrm{n}}$ Aluaro de Ruiagudas y coxe la frente de la plaza y subiendo al Campo de el Castillo todas las Casas de la mano izquierda, y asta la Huerta de $\mathrm{D}^{\mathrm{n}}$ Aluaro de Ruiagudas y a la mano derecha todas. A d [ic] hos sitios se juntaron otros que la Ciudad alargo con mucha venignidad y largueza de los Campos ${ }^{174}$ de el Castillo y su Calle y las de yuso con su calleja ${ }^{175}$ y tambien el sitio de la torre caida que estaua ${ }^{176}$ en los sitios de la plaza y en que estauan antes las Carnizeria, y en retorno destos sitios quedo el Colle[gi] obligado $\hat{a}^{177}$ comprar el sitio necezesario para d[ic]has ${ }^{178}$ Carnizerias y de darlas edificadas, y cubiertas de texado â texavana como consta de el decreto en 25 de Abril de 1680 dio la Ciudad

164 D2 en lugar del párrafo: «Siguo a lo referido ... de jente jamas visto.» dice: «El Domingo siguiente se hizo la doctrina General, en que el num[er] $]^{\circ}$ de gente fue el mayor en funcion alguna se vio otra vez.»

165 D2 añade: «que fueron todas».

166 D2 en lugar del texto: «y se remato ... christiana y platica» dice: «en que se explico la doctrina christiana, y se hizo la platica que dio fin a esge glorioso empleo.»

167 (Al margen) Eleccion de sitios.

168 D2 en lugar del párrafo: «El Pâdr]e prov[incial] ... de Cordoua» escribe: «El P[adr]e Pedro Geronimo de Cordoua Provincial de esta prouincia de castilla». Petrus Hieronymus de Cordoba [Montilla 1621-la última vez que aparece en un catálogo de Castilla es en el año 1693].

169 D2 en lugar de «en» dice: «a».

170 D2 en lugar de: «de» escribe: «del d[ic]ho año».

171 D2 dice: «para».

172 D2 en lugar de: «de sitio» escribe: «de los sitios para el edificio de».

173 D2 añade aquí: «y desde la misma esquina».

174 D2 en lugar del texto: «A dichos sitios ... y largueza de los» pone: «A la compra de estos sitios y casas, juntan los sitios de los campos».

175 D2 añade en este lugar: «que la Ciudad dio a la Comp a con mucha benignidad y largueza».

176 D2 en lugar de «estaba» dice: «esta».

177 D2 en lugar del texto: «y en retorno de estos sitios ... obligado â» dice: «de las carnicerias arruynadas quedo La compa con la obligacion de».

178 D2 en lugar de: «dichas» dice: «otras». 
ante Juan de Mendijur su secretario. Y en efecto compro y edifico ${ }^{179}$ habiendo hauido muchas dudas y reparos sobre la tal fabrica de Carnizerias p[o]r el Collegio. Hubo tam[bi]en varios reparos y parezeres sobre si $\mathrm{d}[\mathrm{ic}]$ has Carnicerias hauian de tener o no patio, y ultimam[en] te resoluieron se hiziese sin patio, aunque presto reconzieron el Yerro, por hauer quedado sin luzes. Quedo asi mismo â cargo de el Collegio introduzir el agua desde el Calze en el matadero como se ejecuto conforme lo quiso la Ciudad, y aun excedio el Collegio $\mathrm{p}[\mathrm{o}]^{\mathrm{r}}$ obiar algunas disensiones que se iban crispando, hauiendo profundado una conduta muchos estados â vastante costa.

${ }^{180}$ Adquiridos los sitios referidos vendijose, teniendo auierto los $\mathrm{Ci}$ mentos, en un pedazo de la parte de la plaza y se echo la primera piedra en 20 de Mayo de 1680. Hizo esta sagrada funzion el $\mathrm{S}^{\mathrm{r}} \mathrm{D}^{\mathrm{n}}$ franz[is]co Ortiz de Zarate y Salzedo comisario del s ${ }^{\text {to }}$ ofizio, y venefiziado mas [Fol. numerado 4v] antiguo de las Iglesias unidas esta ciudad con asistenzia del Sor $D^{n}$ Mart[i] ${ }^{n}$ de Varona Garondo y Luyando, que se allo con todo su ayuntam[ien]to, y con el concurso de todos los caualleros y vezinos de la Ciudad que todos asistieron con consuelo que les mostraron ${ }^{181}$ pu[bli] $]^{\text {co }}$ en los Parabienes que dauan al $\mathrm{Pe}$ Prov[incia $]^{1}$ y demas Pes.

${ }^{182} \mathrm{Sin}^{183}$ embargo de que la Ciudad instaua para que se pusiese Maestro de escuela juzgo el Pe Prov[incia $]^{1}$ con los Pes consultores de

179 D2 en este pasaje se aparta bastante del texto propuesto que comienza: «Y en efecto compró ... y se echo la primera piedra en 20 de Mayo de 1680» y lo sustituye por el siguiente: «y este sitio y el de los solares que eran de Don Antonio de Luyando, que esta en la plaza y Le compro la Compa para este fin y edifico con mucha costa, pero menos y de la q[ue] debe a la M[uy] N[oble] Ciudad la parte de la plaza, bendixose, y se hecho la primera piedra en 28 de Mayo del d[ic]ho] año». Nótese la diferencia de fecha para la primera piedra. D1 $=20 \mathrm{de}$ Mayo, $\mathrm{D} 2=28$ de Mayo.

180 (Al margen) Ponese la 1a Piedra.

181 D2 en lugar de: «mostraron» dice «mostraban».

182 (Al margen) Maestro de escuela.

183 A partir de este punto del escrito el D2 se aparta de la letra de lo recogido en el texto transcrito y aunque muchas ideas y frases se repiten, se hace necesaria una transcripción completa del documento D2 desde este momento:

«18 Auiendose ajustado las materias de la fundacion con toda felicidad entre la Ciudad y el P[adr]e Prou[incia]l el P[adr]e Pedro Geron[im]o de Cordoua se dio principio al derrivo de algunas casas, que fueron Las que estaban haciendo frente a la plaza; Despues se comenzo el edificio de las carnicerias, y aqui tuuieron principio algunos pesares que dieron alguna mortificacion al $\mathrm{P}$ [adr]e Prou[incia]l que ya lo era el P[adr]e Pascual de casanueva [Pascasius de Casanueva: Cádiz abril 1629-su nombre aparece por última vez en el Catálogo de Castilla de 1705]; y al P[adr]e Pedro Geron[im]o de Cordoua, y no falto su porcion al P[adr]e Martin de Lazcano superior de esta casa de fundacion.

19 Fue el caso que auiendo embiado La Ciudad sus comisarios al P[adr]e Prouincial para sauer de su R[everenci]a si quedaba al cargo de la Compañia no solo el comprar el sitio necesario para las carnicerias sino tambien el darlas edificadas y cubiertas de texado a texa Vana, respondio que no solo La compra del sitio necesario para las carnicerias sino el darlas edificadas y cubiertas de texados atexado atexa Vana quedaba al encargo de la Compa. Esta respuesta lleuaron los comisarios a la Ciudad, y por ella mesma hicieron su decreto narrando en el 
Prov[inci] a que no se deuia poner asta acauar la fabrica de $\operatorname{la} \operatorname{Ig}[\operatorname{lesi}]^{\mathrm{a}}$ y Collegio; no obstante allandose visitando este Collegio el Pe Prov[incia] ${ }^{1}$ Gregorio Sarmiento ${ }^{184}$ por el mes de octu[b]re de 1689 , y siendo las instanzias de todos los vezinos, y que no poniendo escuela estarian muy mal vistos los Pes, con muchas desazones y ningun gusto, ofrezio la escuela al

con las palabras siguientes y su R[everendisim]a ha respondido por dicho de d[ic]hos Legados que ha de ser a cargo del compañia comprar el sitio necesario para d[ic]has carnicerias y darlas fabricadas con sus paredes y texado a teja Vana.

20 Queriendo pues el P[adr]e Martin de Lazcano dar principio al edificio de las carnicerias, y sauiendo que la obligacion era cubrir el sitio necesario trato de executarlo dexando descubierta La mitad, pues assi quedaba cubierto todo lo que necesitan las oficinas de las carnicerias que era muy capaz y quedaba descubierto otro pedazo de los sitios con que tendrian todas Las oficinas Luz y oreo de los vientos. [Nota al margen derecho: "edificio de las carnizerias sus dificultades"] Algunos de la Ciudad y que en las materias del gouierno tienen la primera mano dieron en que se auian de cubrir todos Los sitios; porque assi se auia contratado con el P[adr]e Pedro Gerónimo de Cordoua. Su R[everencia]a auiendo sido preuenido de la pretension de la Ciudad respondio no auia tal obligacion de cubrir todos Los sitios; son sus palabras esta obligacion es cierto que no la ay. Con esta respuesta del P[adr]e Prov[incia]l La manifesto al Alcalde D. Martin de Barona, y de ella hizo sauedor el P[adr]e Martin de Lazcano a D. Bentura Ortiz de Zarate y Salcedo que fue quien mas ynsto en que se auian de cubrir, asegurandoles que no era arbitro para hacer Una fabrica tan costosa sin Orden del P[adr]e Prov[incia]l con que la Ciudad escrivio al P[adr]e Pascual de Casanueva que lo era ya, y emuio el decreto hecho escrivio assi mesmo al P[adr]e Pedro Geroni[im]o de Cordoua. En la carta el P. Prouincial dice La Ciudad que quedo a cargo de la compa el cubrir todo el sitio, siendo assi que a su cargo solo quedo comprar y cubrir el sitio necesario como se dice en el mismo decreto aquel refiere: y fue su prueba contraria a la conclusion que yntentaba como se Ve en las mesmas palabras del decreto.

21 El P[adr]e Prou[incia]l respondio a la Ciudad con reconocimiento de lo mucho debia la comp a las honras que auia reciuido y que en el Particular de lo contratado con su antecesor el P. Pedro Ger[ronim]o de Cordoua lo remitia a los señores comisarios que auian tratado este punto y dirian el hecho de lo contratado, y que deseaba dar gusto en todo a su S[eñori]a.

22 El P[adr]e Pedro Geron[im]o de Cordoua respondio con Viueza y como quien sentia que se diese menos credito a su dichos, y que se pusiese duda en la Verdad que profesô siempre. Tambien se remitio a los Señores Comisarios, para que se supiese de sus modos el hecho; $\mathrm{y}$ al mesmo decreto que lo decia $=$

23 La Ciudad sintio esta respuesta y de aqui resulto el que se suspendiese la prosecucion de la fabrica de las carnicerias, asta que con la eleccion de nueuo regimiento el P[adr]e Martin de Lazcano deseoso que estas carnicerias se concluyesen, Propuso su deseo al nueuo alcalde que lo era D. Miguel de Herran y Romezate, y su m[e]r[ce]d mostro mucho gusto en esta propuesta, y Voluiendo a ella otro dia Junto con su Procurador Gen[enera]l que lo era Don Pedro Agustin de Murga determino La forma en que se auian de fabricar Las carnicerias, y [Nota al margen derecho: Decreta la Ciu[dad] se hagan las carnicerias con patio] para asegurarse del hecho de lo contratado entre los señores comisarios y el P[adr]e Pedro Geron[im]o de Cordoua, Vio Una copia del decreto, y dixo que por el solo quedo a cargo del Compa el cubrir el sitio necesario, no todo, pues solo su mitad vastaba. Añadio el P[adr]e Martin De Lazcano, que tenia orden del P[adr]e Prouin[cia]l para cubrir todos los sitios, si la Ciu[da]d lo quisiese, por que no reparaba la Compa en el gasto, pero debia mirar a lo se contrato con el P[adr]e Pedro Geron[im]o de Cordoua, para que no pareciese que su R[everenci]a decia otra cosa del hecho, ni que la Compañia faltaba a su obligacion y encargo; Y desestimando estos respetos, y q[ue] La Compa deseaba seruir a la Ciudad en quanto reconociese se- 
Procurador General que lo era $\mathrm{D}^{\mathrm{n}}$ Ant[oni] Luyando, con la calidad de que la Ciudad auia de ratificar en ayuntam[ien $]^{\text {to }}$ pu[bli ${ }^{\text {co }}$ general el decreto de 25 de Abril de 1680 para que la Compa estubiese segura en su sitio.

${ }_{185}$ Propuso lo referido d[ic]ho Sor Procurador General en ayuntam[ien] to $\mathrm{pu}[\mathrm{bli}]^{\mathrm{co}} \mathrm{y}$ aunque persuadio con razones a los vezinos para que lo hiziesen,

ria de su agrado: el Señor Alcalde y su Procurador General determinaron que se fabricasen las carnicerias dexando patio en medio, y se hizo planta, La qual embio el S[eñ]or Alcalde al P[adr]e Martin de Lazcano con Bentura de Garay es[criba]no de ayuntamiento y carta por Ciudad en que decia que se executase aquella planta. Y luego al punto se dio principio en la misma forma que estaba puesta en la planta.

24 En este tiempo hizo ausencia el Alcalde, y hallandose el segundo Alcalde que lo era Don Aluaro de Riuaguda [Nota al margen derecho: Decreta la ciudad se hagan sin patio todas cubiertas] con sus dos rexidores, y algunos caualleros de la Ciudad que eran D. Juan Baptista de Zarate y Don Bentura de Zarate Don Balcatin de quincoces, D. Pedro de la Cantera, y Don Juan de Bardui a tratar negocios de la Ciudad, salio un mandato, y se yntimo ines[te]n[s]o a los oficiales que estaban trauaxando en las carnicerias, que pena de cinquenta ducados no prosiguiesen en aquella fabrica.

25 Auiendose notificado este auto a los oficiales, llamo el Alcalde al P[adr]e Martin de Lazcano (que aun ygnoraba este acuerdo de la $\mathrm{Ciu}[\mathrm{da}] \mathrm{d}$ ) y le dixo que por quanto el edificio de las carnicerias no se hacia como debia, porque las paredes quedaban descubiertas, y toda la fábrica muy ahogada. El P[adr]e Martin de Lazcano estrañando que de parte de la Ciudad se huuiese mandado a los oficiales que cesasen de la obra, y de que no se huuiese auisado de los reparos que auian hecho para dar razon de la traza del edificio, pidio su R[everenci]a al $\mathrm{S}[\mathrm{en}]$ or Alcalde que se siruiese de voluer a llamar a los mismos rexidores y caualleros que auian antes concurrido; y estando Juntos los dos rexidores y Don Juan Bap[tis]ta y D. Bentura de Zarate; dio Lo primero su quexa, de que se huuiesen Unanimes conformado en que cesase La obra con demonstracion tan publica, y tan poco fauorable a su credito, sin que se le huuiese hecho sauer ni se le huuiese preguntado la razon por que fabricaba: a esto dixo Uno de los rexidores (Fran[cis]co de Zalora) Señores, confesemos que lo auemos herrado en no auer primero sauido del P[adr]e R[ecto]r La razon de lo que executaba.

26 Despues de auer dado su quexa, mostro el P[adre] R[ect]or al alcalde y a los demas que estaban presentes La planta de la traza que se auia de executar y La carta que la Ciudad escriuio a su $\mathrm{R}$ [everenci]a pidiendole executase aquella traza que era con patio, y auiendo visto la traza y la carta, solo dixeron, que no auian sauido cosa alguna. El P[adr]e R[ect]or viendo que ynsistian, en que las carnicerias se hiciesen todas cubiertas dio su R[everenci]a quenta de todo al P. Prov[incia]l que lo era el P. Pascual de Casanueua, y su R[euerenci]a escriuio que se hiciesen enteram[en]te cubiertas, aunque no por obligacion, sino por quitar desazones, no obstante Lo mucho que auia de crecer la costa: y assi se executaron: y quedaron sin Luz, y sin ores [= "orear"] tan necesario uno y otro para tales oficinas. Muy en breue reconocieron todos los vecinos el hierro, pues Lo es grande dexar sin patio tal fabrica.

27 Quedo assi mesmo a cargo del Coll ${ }^{\circ}$ yntroducir el agua desde el calce [= cuña] en el matero para su limpieza, como se executo conforme lo quiso la Ciudad, quien puso por condicion que el collo auia de abrir y de recorrer desde La esquina del matero toda la conducta del agua asta el fin de la calle de Cantarranas dandola su expediente al desembocadero del sumidero de la casa de Miguel de Paona: y auiendo el P. R[ect]or comenzado a recorrer y a limpiar la $\mathrm{d}$ [ic]ha conducta conforme a la condicion puesta; parecio a algunos que quedaria la conducta mexorada si se profundase mas, y si se dexase toda de canteria, y bien enlosada La cubierta y el suelo; y el P. R[ect]or aunque crecia mucho la costa y no auia obligacion, lo hizo por quitar diferencias. Como tambien por los mismos motivos de paz a largo esta conducta muchos es- 
no tan solam[en] te no lo hizieron; sino que antes se leuantaron varias calumnias contra la Compa. Sin embargo de que d[ic]ho Procurador General propuso, que la Compa alargaria el sitio de la neuera para que quedase por de la Ciudad, como también, los sitios de la otra parte de los muros, que miran a la Huerta de S. Fran[cis] ${ }^{\text {co }}$ quedandose el Collegio solo con los

tados metiendola por La huerta de Miguel de Paona asta sacarle a la ronda que mira la conb[ent]o de S. Fran[cis]co.

n..$^{\circ} 28 \mathrm{En} \mathrm{el} \mathrm{n.}{ }^{\circ} 17$ se dice que la Ciu[da]d dio los campos del castillo, quedando el collo con la obligacion de hacer neuera en el sitio que la Ciudad quisiese, por la neuera [Al margen izquierdo: Campos del castillo. Decreto del 1680 dicen que es nullo] que d[i]hos campos tiene la ciudad. quedo assi mesmo a cargo del Collo hacer las carnicerias, como se dice en el d[ic]ho n. ${ }^{\circ}$ 17. Estos tratados Los hizo La Ciudad con su ayuntam[ien]to con asistencia no solo de todos los del gouierno, sino de casi todos los caualleros de ella, como parece del decreto de 25 de Abril de 1680. Parecio a algunos, que todo lo tratado entre la Ciudad y el P. Prov[incia]l el $\mathrm{P}$ [adr]e Pedro Geron[im]o de Cordoua era nullo, y que no pudieron darse al collo sitios algunos assi de calles como de los campos del castillo: La razon de la nullidad La fundaban en que tales concesiones, no las puede hacer la Ciudad sino en ayuntam[ien]to general, quien mas ynsistio en esta nullidad fue Don Bentura de Zarate, y sus ynfluxos pasaron a la plebe, que abrazo muy bien La nullidad del decreto de 80 .

29 A este mismo tiempo pedia La Ciudad al P. Prov[incia]l pusiese maestro de niños de escuela. El P. Prov[incia]l con todos los padres consultores de prov[inci]a juzgaron que no se debia poner tal maestro, asta acauada la Ig[esi]a y la vivienda necesaria y renta para sustentar los sugetos que huuiese de auer, pues era condicion expresada en las escrituras y con la exclusiua que dice y no antes. Hallabanse otras razones para no ponerse La escuela por el gasto que crecia, y porque pasarian a pedir maestro de gramatica. [Al margen izquierdo: ofrece el P. P[rovincia]l La escuela] No obstante el P[adr]e prov[incia]l el P. Greg[ori] ${ }^{\circ}$ Sarmiento hallandose visitando en este collo el mes de octubre de 1689, y viendo las ynstancias de todos los Vecinos, y que no poniendo La escuela estarian muy mal vistos Los padres, con muchas desazones, y ningun gusto, ofrecio La escuela al Procu[rad]or gen[era]l que lo era D. Ant ${ }^{\circ}$ de Luyando con la calidad que la Ciu[da]d auia de ratificar en ayuntam[ient]o publico general el decreto hecho el d[ic]ho dia 25 de Abril de 1680 para que La Compa estuuiera segura en sus sitios.

30 Parecio al procurador general que no se podia negar lo que pedia el P. Prov[incia]l y que el ratificar el d[ic]ho decreto era de Justicia, y que la falta de solemnidad que se cometio el año de 1680 se debia deshacer haora, ratificando en ayuntam[ient]o general Lo que se capitulo entonces en ayuntamiento [tachado: general] particular; pues la compañia creyendo, que eran validos todos los contratos hechos con la Ciudad en ayuntam[ient]o particular; y mas siendo llamados a el todos o casi todos los caualleros de La Ciudad, hizo Las compras de las casas, para en sus sitios edificar la Yglesia, como lo hizo, y edificar los quartos para la viuienda a su tiempo, como en sitios proprios pues Los dio la ziudad obligandose el collo a dar edficadas las carnicerias, como de hecho las edifico y a dar hecha la neuera, como la haria luego que la Ciudad tuuiese gusto. Y siendo esta condicion puesta por el P[adr]e Prov[incia]l tan justa como se ve no fue admitida de todos porque huuo algunos que mouieron los animos del pueblo y persuadieron con fuerça a que siendo nullos los decretos del año de 1680, ningunos sitios eran de la compañia. [Al margen izquierdo: ayuntamiento general. Sus voces]. Estos ynfluxos tuuieron tanta fuerza en los animos del pueblo y en algunos otros, que auiendose Juntado en ayuntam[ien]to general el dia 27 de Diciembre de 1689, y auiendo D. Anto de Luyando como procurador general comenzado a proponer La materia a que fueron conuocados, se atraueso Don Bentura de Zarate, y sin dar Lugar al procu[rad]or gen[enera]l a que proseguiese en su proposicion, para que oyda de todos los Vecinos se deliberase lo que mas conuiniese, todos Leuantaron la Voz como 
prezisos para una Huerta. Las calumnias eran tales, q[ue] llegaron â dezir, ô dar â entender que la Compa retenia los miles de r[eal]es que remitio el Sor fundador para obras pias como tam[bi]en el caudal de muchos millares de fanegas de trigo que auia ofrezido para que hubiese un deposito de trigo en la Ciudad. Viendo el $\mathrm{S}^{\mathrm{r}}$ Alcalde la confusion levanto $\mathrm{p}[\mathrm{o}]^{\mathrm{r}}$ entonces el

gente del pueblo y segun venian ympuestos, y algunos de ellos leuandando los dedos dixeron en Voz alta, nada a la compañia, vayan fuera que no los avemos menester. El procurador general viendo que no le dexaban ablar, y que el Vulgo estaba reuelto contra La compa tuvo empuñada La espada, y no detenerle D. Diego de Zarate huuiera sin duda hecho demonstracion ruydoza.

31 La proposicion que llevaba el procurador general era: que el p[adr]e Prouincial pondria luego la escuela pero que la Ciudad auia de ratificar en ayuntam[ien]to publico el decreto de 1680 , y que La compa alargaria el sitio de la neuera, quedando esta para la Ciud[a]d y que alargaria los sitios de la otra parte de los muros que miran a la huerta de S. Fran[cis]co quedandose con los sitios precisos para su huerta. [Nota en el margen izquierdo: Calumnias]. Nada pudo proponer el procurador gen[era]l por la confusion de los del pueblo, y de quien los tenia ympuestos: y Uno de estos añadio otras vozes muy contra la fidelidad de la compa pues dio a entender que compa retenia quarenta mil pesos que el Señor fundador auia ofrecido para obras pias en beneficio de los pobres de la Ciudad, como tambien del caudal de muchos millares de fanegas de trigo que tambien auia ofrecido para que huuiese Un deposito de trigo en la Ciu[da]d y aunque los mas conocieron que no auia fundamento para pensar contra la compa cosa contra su credito, muchos de la plebe las admitieron por algunos dias, aunque presto se desengaron (sic). El alcalde que lo era D. Miguel Herran Viendo la confusion y que nada se ablaba en orden, levanto el ayuntam[ien]to por entonces.

32 El dia siguiente 28 del d[ic]ho mes de Diciembre y d[ic]ho año de 1689 se sento en la sacristia de Santa Maria Un ayuntamiento, que se compuso de asta quarenta Vecinos de caualleros y republicos primeros; en que se decretaron diversos puntos, que decian que se diesen a la compa tales y tales sitios: [Nota al margen izquierdo: ayuntamiento en la sacristia] y aunque envolvian algunas condicciones duras para la comp ${ }^{a}$ Las hubiera admitido el P. Prov[incia]l por La paz y La quietud, pero no las admitio por no auerse decretado en ayuntamiento publico general; pues este defecto, en que su estimacion los decretos del año de 1680 los hizo nullos hacia que fuesen igualm[en]te nullos, aunque se huuiesen hecho en Un ayuntamiento de tan crecido numero de republicos y los mexores con que quedaron todas estas dependencias suspensas $=$

$33 \mathrm{Y}$ auiendo venido a visitar este collo el mesmo P. P[rovincia]l en 28 de mayo de 1691 embio la Ciudad dos capitulares suyos a darle la bien venida, y pedirle pusiese La escuela, asegurando a su R[everenci]a que en ayuntamiento publico se ratificarian todos los decretos antecedentes hechos en ayuntamientos particulares: como se hizo el dia 3 de Junio de d[ic]ho año de 1691. Cuyas copias signadas por Matheo de Xocano estan en el archivo del collo. [Nota al margen izquierdo: Confirma el ayuntamiento general todos Los decretos. Ponese la escuela] Este ayuntami[en]to se compuso de asta los mas plebeyos, oyeron todos con grande silencio y nemine discrepante Votaron todos que se ratificasen todos Los decretos antecedentes, y que el P. Prov[incia]l hiciese eleccion de los sitios que gustase; y en nombre de su R[euerenci]a y por su comision La hizo el P. V. R. el P. Martin de Lazcano y dexo hecha la demarcacion como se expresa en los d[ic]hos decretos, asistiendo a la dicha demarcacion el Señor Alcalde y Señores procu[rad]or gen[era]l y ex[ecutos]e y tambien Los mas de los caualleros de la Ciud[ad] y casi todos los Vecinos de ella. No asistio a este ayuntam[ien]to gen[era]l D. Miguel de Herran por hallarse ausente pero solicito mucho que se hiciese lo que la compa pedia, ablando a muchos que estaban mal ynformados. Tampoco asistio Don Bentura de Zarate por enfermo. [Para entender esta clase de enfermedad, véase lo dicho más arriba en esta nota en el $n^{\circ} 30$ de la p. 177].

34 Uno de los encuentros y que ha dado que Vencer, ha sido La condicion que es La de el $\mathrm{n}^{\circ} 3^{\circ}$ y estando expresado que el collo pueda comprar para su gasto todo lo necesario y pagar- 
ayuntam[ien $]^{\text {to }}$. tam[bi] en llegaron â dezir en voz alta levantando los dedos: nada a la Compa vayan fuera que no los auemos menester: El Procurador gen[era $]^{1}$ viendo que no le dejauan ablar, y que el pueblo estaua rebuelto con[tr] a la Compa tubo empuñada la espada, y a no deternele $\mathrm{D}^{\mathrm{n}}$ Diego Zarate hubiera echo sin duda demostrazion ruidosa. Y aunque [Fol. nu-

lo en su proprio peso sin dar quenta de ello al ayuntam[ien]to ni lleuarlo al peso publico de la Ciudad: [Nota al margen izquierdo: Peso Real] No obstante esta expresion, salio Uno de los abogados de la Ciudad ynterpretando la dicha condicion, diciendo que se debia entender; que el collo no tenia obligacion de dar quenta al ayuntam[ien]to de lo que huuiese traydo con las requas proprias del collo para su consumo, ni que en tal caso deia lleuar al peso publico; pero que todo lo que comprase de los harrieros fuese dentro o fuera de la Ciudad lo auia de lleuar al peso publico de la Ciudad y pesarlo en el, y dar quenta de ello al ayuntam[ien]to. Esta ynterpretacion era ynjustisima; Lo Uno por ser contra lo expresado en el d[ic $]$ ho $n^{o} 3^{\circ}$. Lo otro por ser contra la ymmun[ida]d y priuilegios de la compa.

$35 \mathrm{La}$ autoridad de tan docto abogado y sus ynfluxos fueron tan poderosos, que apenas huuo en la Ciudad quien no abrazase la tal ynterpretacion, y conuenian muchos en que se auia de obligar al collo a que hubiese de dar q[uen]ta al ayuntam[ien]to de todo lo que comprase para su abasto, y lleuarlo al peso publico y pesarlo en el y para que se observase hiciesen requerimientos a los harrieros y puesto penas, si traxeren cosa alguna al collo sin auer primero lleuadolo al peso de la Ciudad. Consultaronse en Madrid los mexores abogados y theolo[go]s, y auiendo Visto La clausula expresada en el d[ic $]$ ho $n^{\circ} 3^{\circ}$ respondieron uniformes que yncurrian en las penas puestas en la Bulla de la Cena los que obligasen a los harrieros [Palabras tachadas: a traer al collo] a lleuar al peso de la Ciudad los mantenimientos que traxesen para el collo y aunque estos pareceres, se leyeran al d[ic]ho abogado de las ynterpretaciones en presencia del P. Prov[incia]l, el p[adre] Juan Nieto, y del P. Antonio Casaueo su secret[ari]o quedo en el mismo dictamen; y se continuaron contra los harrieros las penas puestas.

36 Pasado algun tiempo hallandose en ayuntam[ien]to el alcalde con su procuradoro g[enera]l Rexidores, ablo el procurador que lo era D. Juan de Berastegui, y abogado consistorial propuso el caso, y auiendo uisto los tratos de la fundacion y en ellos el $\mathrm{d}[\mathrm{ic}] \mathrm{ho} \mathrm{n}^{\mathrm{o}} 3^{\mathrm{o}}$ reconocieron la grauedad del caso, y embiaron recaudo con el mesmo procu[rad]or gen[era]l diciendo que al collo se le guardaria sin ynterpretacion alguna todo lo expresado en la escrip[tur]as de fundacion $\mathrm{y}^{\mathrm{o}} 3^{\circ}$ y assi corre. El P. R[ect]or pidio Una copia de este nueuo decreto; respondiosele que auia sido resolucion solo in Voce, porque estando tan expresada la condicion del $\mathrm{d}[\mathrm{ic}] \mathrm{ho} \mathrm{n}^{\mathrm{o}} 3^{\circ}$ no se necesitaba que sobre la misma condicion se hiciese nueuo decreto.

37 Auiendo el collo comprado diferentes casas y sitios para la ereccion y templo comenzo a componer lo preciso para la Viuienda de prestado, y estando trauaxando los oficiales se les notifico Un decreto que el dia 2 de Junio de 1681 hizo La Ciud[a]d y por el se les mando, cesasen en las d[ic]has obras; decreto assi mesmo que el d[ic]ho decreto se notificase al P. Martin de Lazcano R[ect]or del collo Lo qual todo se hizo. El P. R[ect]or pidio traslado al secret[ari]o que lo era Bentura de Garay, Pero le mando el alcalde que lo era Don N. que no lo diese: pero Le dio simple y queda en el archiuo: y cesaron los oficiales. Este decreto y notificaciones causaron grande admiracion aun en los que menos entendian, pues no auia quien no reconociese el alcalde y demas del gouierno se yntroduxeron a Jueces de los religiosos; por esto y por que venian para dar Las obras precisas para la morada de los religiosos y en sitios suios, persuadian algunos afectos al collo al P. R[ect]or que pidiese a la Ciu[da]d leuantase La notificacion, que pidiendola su R[euerenci]a la leuantaria la Ciudad. El P. R[ect]or respondia, que no queria La compañia fabrica contra la voluntad de la ciudad, y que no se daría golpe menos que La ciudad embiase recado con el mismo secret[ari]o en que le hiciese sauer ese su gusto continuase con las obras comenzadas y que Juntamen[en]te se auia de deshacer el decreto. Viendo que el P. R[ect]or estaba 
merado 5r] los mas conozieron que no hauia fundamento para pensar contra la Compa, no dejaua de hauer algunos que estubiesen en persuasion contraria por algunos dias, pero se desengañaron muy presto. El dia 28 de Diziembre de d[ic]ho año de 1689 se junto en la sachristia de Santa Maria ayuntamiento, y aunque hubo varias razones ${ }^{186}$ quedaron suspensas

firme en esta resolucion, en ausencia del alcalde principal, que hizo el decreto de cesacion, el segundo alcalde D. Aluaro de Riuaguda con los demas del gouierno resoluio que Viniese Un regidor y el secret[ari]o al p[adr]e R[ect]or y que en su presencia se rasgase el decreto, como se hizo y pidieron a su R[evernci]a continuase en las obras, y obrase lo que quisiese.

[Nota al margen izquierdo: Escuela] Diose principio a la escuela de niños el dia $16 \mathrm{de} \mathrm{Ju-}$ lio de 1691 su maestro el Herm[an]o Pedro de Caneda.

[Nota al margen izquierdo: Dedicación de la Iglesia] Dedicose la Yglesia el dia de N.P.S. Ignacio de 1694 auiendo primero bendiciendose conforme el ceremonial a que asistieron con sobrepellices muchos de los s[eñor]es beneficiados el dia 30 por la tarde se traslado procesion alm[edio]d[i]a, con licencia del S[eñor] Ob[is]po el S[antísi]mo sacram[en]to desde la parroquial de Santa Maria con asistencia de todo el Cauildo eclesiastico, y auiendo colocado a su Mag[esta]d diuina en el trono del altar Mayor canto el cauildo las visperas: el dia canto y entono La misa el cauildo, predico el P. Fr. Dom[ing]o de Eguiluz del comb[ent]o de san fran[cis]co por su comunidad; descubierto el S[antisi]mo por la tarde cantaron las visperas Los señores beneficiados. Despues de las visperas hicieron los muchachos de la escuelas (sic) sus papeles de representacion, y danzas, todo con mucha gracia. La ciu[da]d asistio a todas las fundacion (sic) de la vispera y del dia; tuuo fuegos y toros de la tierra.

[Nota al margen izquierdo: Jubileos del mes] No estan fundados los Jubileos del mes, pero se celebran descubierto el S[antisi]mo los terceros Domingos; y se dio principio el tercero Domingo de Junio de 1695, por orden de N. P. General por carta de 20 de Nou[iembr]e de 1695.

[De otra mano] Murio el Marques, hijo de Nuestro fundador el dia 13 de Mayo del 1702, [Nota la margen derecho: Muerte de Nuestro Patron =] segun las cartas de la señora Marquesa de Março de 1703 qye escribio dando la Noticia al Rector de este collegio, y al P[adr]e Martin de Lazcano que estan en el Archivo y el collegio; parece dexo una hija. Murio en Lima de indias, donde tienen su Habitacion. =

Entro a ser R[ect]or de este collegio en 7 de Mayo de 1703 el P[adre] Manuel Herrera: y en sus tiempo; reconocio ser la Gente de esta ciudad, por su interes, affecta a la compañia: por si Les prestan ó Regalan, como se ha visto en las fiestas, que celebra el collegio entre Año: Assy eran antes ecclesiasticos, y seglares, por que con unos, y otros gastaba, y mucho; y haora, sola La Nobleça, y alguno, u, otro ecclesiastico acuden $=$

Despues de quitados algunos gastos superfluos: esto lo observo por los tres Años: $1704 y$ 1705 y 1706.

[Nota al margen izquierdo: Poço] Hiçose en beneficio del collegio, en tiempo de este $\mathrm{P}[\mathrm{adr}] \mathrm{e}$ Retor $=$ Un poço, que serbira, y sirbio desde luego para alibio del collegio $=$ Retexose todo lo fabricado de nuevo; y se recorrieron Las Maderas de texados, yglesia, y capilas = [Nota al margen izquierdo: Panera, Retexar, Despensilla] Hiçose una Panera nueba, junto a la Porteria Principal; tambien se hiço una despensilla debaxo de la escalera principal = Puerta nueba a la Porteria Reglar, que sera en adelante = [Nota al margen izquierdo: Sacristia y ylesia] Mas quatro Acheros, pies para Los ciriales, y la cruz: tumba, y armaçon del funeral o para dia de Animas = Recorriose La sacristia; se remendaron casullas, y se hizo una Arca de nuebo, quatro sobrepellices nuebas = Mas seis Bancos de Respaldo; para La iglesia = comprose un clavicordio para Las fiestas italiano $=$ un patio de facistol negro, una Almoada Negra con sus Borlas $=$ comprose un Misal, y se compusieron los tres antiguos = Doce ramilletes de flores: vestido al Niño Jesus, y su Diadema = Adorno nuevo al Monumento. 
las cosas por entonzes, asta que auiendo venido a visitar este Collegio el Pe Prov[incia] ${ }^{1}$ embio â su R[everenci] ${ }^{a}$ la Ciudad dos Capitulares suyos â darle la vienvenida, y a pedirle pusiese la escuela asegurando â su R[everenci] ${ }^{\mathrm{a}}$ que en ayuntamiento pu[bli] ${ }^{\text {co }}$ se ratificaron todos los decretos como se hizo el dia 3 de Junio del año de 1691 ante Matheo Cosano, cuyas copias estan en el Nicho $1^{\circ}$ del Archiuo n[umer]o 10. Dicho ayuntamiento se compuso de asta los mas pleueyos, y sin embargo fue sin discrepanzia alguna. Mediante lo qual el Pe Mart[i]n de Lazcano ${ }^{187}$ Vize R[ect] ${ }^{\text {or }}$ hizo la demarcazion de sitios en nombre de el Pe Prov[incia] ${ }^{188}$ como se expresa en ${ }^{189} \mathrm{~d}$ [ic]hos decretos. Por todo lo expresado arriua y en atenzion a que auia cumplido la Ciudad con d[ich]a Confirmazion, se puso la escuela, a la que se dio prinzipio el dia 16 de Julio de 1691 maestro el M[aestr] ${ }^{\circ}$ Pedro de Caneda.

Sobre lo expresado en el Capitulo $3^{\circ}$ que conzede al Collegio facultad ${ }^{190}$ para que sin lleuar el Peso R [ea ${ }^{1}$ pueda comprar todos los abastos nezesarios se ofrezio una disputa, y es: Que uno de los Abogados

[Nota al margen izquierdo: escalera] Hiçose una escalera para Las torres: pusose una campana, y se la puso Melena para que se tocase a Buelo = [Nota al margen izquierdo: Quadros] Pintose el quadro Grande, que esta en el transito del costado y de la iglesia = Un quadro Pequeño de Jesus Maria y Joseph con la trinidad S[antisi]ma otro de los S[an]tos Martires del Japon: Hecharon Rejas a varias ventanas de Hierro $=$ [Nota al margen izquierdo: Quarto nuevo y cocina empeçose el quarto nuebo para La vivienda al medio dia, y la cocina nueba = [Nota al margen izquierdo: Guerta] compraronse doscientas vigas de pino para el quarto nuebo $=$ se plantaron Arboles, se insertaron otros, y se Limpio La Guerta; pusieronse muchos sarmientos alrededor de la Guerta y Muchos Arboles frutales.

Antes, que entrase La compañia en esta ciudad; trahian un Predicador, para La quaresma, que por dicho de ellos mismos les costaba, cien ducados cada Año; y alternaban en este Gasto ciudad, y estado ecclesiastico; y Los trahian, y volvian y sustentaban a los Predicadores; y entre Año para las fiestas; hacian lo mesmo: y Despues, que entro La compañia Les predica, con el combento de san francisco: y con allarse el estado ecclesiastico beneficiado en cinquenta ducados; que corresponden cada Año; y Libres de Gastos con los Predicadores, que no eran de traher, sino tubieran a la compañia: se han portado tan estirados, asi Las assistencias a las fiestas del collegio; que si venrán a las visperas de Nuestro Padre San ignacio; y su dia a la Missa; y visperas segundas; parece venían por lo que con ellos gastaba el collegio; pues Luego; que se quitaron los Gastos, se retiraron $=$ Bien pudieran hacer Reflexion, los señores del cabildo, y pues en la parte de los sermones, se allan seruidos, y de balde; no fuera mucho viniessen a las fiestas y visperas sin La expectativa de que les Regalan: Pero no lo haran $==$ Notese: que los Padres y H[erman]os, que años pasados, se allaron en el collegio; asi se apuraron se gastaria entre quatrocientos, a quinientos R[eal]es. Assi se lo oy, Luego, que vine, a mi Antecesor el P[adr]e Juan Bauptista Mecoleta:»

184 (Viene de la p. 175 nota 184) Gregorius Sarmientus [Córdoba 10.3.1640-En 1705 es el último católogo de Castilla que consigna su nombre].

185 (Viene de la p. 176) (Al margen) Calumnia con[t tra la Compa

186 (Viene de la p. 180) (Al margen) Confrimaz[i] ${ }^{\text {on }}$ sobre sitios.

187 Martín de Lazcano. Superior en el año 1681 en que se fundó el Colegio de Orduña [Pamplona 18.9.1630-muere entre 1705 y 1714].

188 Johannes Nieto [Cantalapiedra 19.10.1721-en el catálogo de la Provincia de Castilla de 1700 ya no aparece su nombre].

189 (Al margen) Ponese la escuela.

190 (Al margen) Sobre abastos p[ar]a el Collegio. 
de la Ciudad salio interpretando d[ic]ho Capitulo, por dezir que aquel solo se deuia entender quando el Collegio introdujese $\mathrm{d}[\mathrm{ic}]$ hos auastos con sus criados, y no quando los Compraua â Arrieros; esta interpretazion vien se reconoce fue injustissima, lo uno por ser contra la Ynmunidad ecc[lesiasti] ca, y lo otro $\mathrm{p}[\mathrm{o}]^{\mathrm{r}}$ ser contra $1^{\mathrm{o}}$ capítulo. Sin embargo hizieron requerimientos a los Arrieros, para que no trajesen al Collegio d[ic]hos Abastos sin lleuarlo, al peso pu[bli] co. Esto dio motiuo â consultarse la materia en Madrid con los mejores auogados y theologos, q[uie] nes dieron su dictamen, [Fol. numerado 5v] uniforme diziendo que incurrian en las penas puestas en la Bulla de la Zena los que obligasèn a los Arrieros a lleuar d[ic]hos Abastos al Peso R[ea]'1. Y aunque estos parezeres se leyeron â d[ic]ho Abogado en presenzia de el Pe Prov[incia] ${ }^{1}$ Juan Nieto, y de su secretario el Pe Antonio Caraueo ${ }^{191}$, quedo en el mismo dictamen, y se continuaron con[tr] ${ }^{a}$ los Arrieros las penas puestas, asta que pasado algun tiempo allandose en ayuntam[ien $]^{\text {to }}$ los de esta Ciudad propuso todo lo referido el Procurador General q[ue] lo era $\mathrm{D}^{\mathrm{n}}$ Juan de Verastegui Abogado consistorial, y reconociendo la grauedad de el caso embiaron recado con el mismo Pro[curado]r Gen[era] ${ }^{1}$ al Collegio diziendo que al Collegio se le guardarian $\mathrm{d}[\mathrm{ic}]$ hos capitulos sin interpretaz[i] ${ }^{\text {on }}$ para poder entrar $\mathrm{d}[\mathrm{ic}]$ hos Abastos, sin lleuarlos al Peso R[ea] ${ }^{1}$. Y aunque se pidio copia este Decreto no se dio $\mathrm{p}[\mathrm{o}]^{\mathrm{r}}$ auer sido in voze, diziendo que no nezesitaua, por ser sobre cosa capitulada y $\mathrm{q}\left[\mathrm{ue}\right.$ ] estaua expresada y oblig[a] ${ }^{\text {da }}$ la $\mathrm{Ciu}[\mathrm{da}]^{\mathrm{d}} \mathrm{p}[\mathrm{o}]^{\mathrm{r}} \mathrm{d}[\mathrm{ic}]^{\text {ho }}$ Capitulo $3^{\mathrm{o}}$ y assi corre sin nouedad.

${ }^{192}$ Habiendo el Collegio comprado sitios empezo la fabrica, y estando en ella notificaron al Pe R[ect] ${ }^{\text {or }}$ cesase como lo hizo; causo admirazion esta nouedad aun a los que menos entendian, y no ay que extrañar $\mathrm{p}[\mathrm{o}]^{\mathrm{r}}$ que el Collegio fabricaria en sitio suyo, y los de el reximiento propasaron â ser juezes de religiosos. Y aunque persuadieron al Pe Mar[ti] ${ }^{\mathrm{n}}$ de Lazcano R [ect] ${ }^{\text {or }}$ algunos afectos de el Collegio pidiese a la Ciudad leuantase d[ic]ha notificaz[i] ${ }^{\text {on }}$, no lo quiso hazer dando $\mathrm{p}[\mathrm{o}]^{\mathrm{r}}$ respuesta que no queria fabricar la Compa contra la voluntad de la Ciudad, y que asi no se daria golpe â menos que la Ciudad no embiase recado con el mismo secretario, y juntam[en] $]^{\text {te }}$ se dezisiese $\mathrm{d}[\mathrm{ic}]$ ho decreto. Como le vieron al $\mathrm{Pe} \mathrm{R}$ [ect] ${ }^{\text {or }}$ con esta resoluz[i] ${ }^{\text {on }}$ en ausenzia de el Alcalde prinzipal determinaron el segundo $\mathrm{D}^{\mathrm{n}}$ Aluaro de Ruiaguda y los de el gouierno, q[ue] un reg[id] ${ }^{o r}$ y el secretario viniesen al $\mathrm{Pe} \mathrm{R}[$ ect]or y que en su presenzia rasgasen $\mathrm{d}[\mathrm{ic}]$ ho decreto, como lo hizieron, y pidieron â su R[everenci] a continuase con $\mathrm{d}[\mathrm{ic}]$ ha fabrica.

${ }^{193}$ Dedicose la Ig[lesi] a el dia de N[uestro] Pe $\mathrm{S}^{\mathrm{n}}$ Ygnacio de 1692 auiendose vendezido primero segun el ceremonial que asistieron con sobrepellizes muchos de los $S^{\text {res }}$ Venefiziados. el dia 30 por la tarde se traslado personalm[en $]^{\text {te }}$ con liz[enci] ${ }^{\text {a }}$ de el $\mathrm{S}^{\mathrm{r}}$ obispo el S[antisi] ${ }^{\mathrm{mo}}$ Sacram[en] ${ }^{\text {to }}$

191 Antonius Caraveo [Villafranca del Bierzo 11.10.1638-las últimas noticias que tenemos de él es en catálogo Castilla del año de 1705.

192 (Al margen) embarazan la fabrica.

193 (Al margen) Dedicacion de la Iglesia. 
desde la Parroquial de S[an] $]^{\text {ta }}$ Maria con asistenzia de todo el Cauildo ec[lesiasti] co y auiendo colocado â su Diuina Mag[èsta]d en el trono de el Altar mayor canto el Cau[il] do las Visperas. El dia canto, y entono la misa el Cauildo. Predico el $\mathrm{Pe}$ fr Domigno Eguiluz del Comb[en] to de $\mathrm{S}^{\mathrm{n}}$ franz [is] ${ }^{\text {co }}$ por su Comunidad descubierto el S[antisi $]^{\mathrm{mo}} \mathrm{p}[\mathrm{o}]^{\mathrm{r}}$ la tarde cantaron Visperas los Sres Veneficiados. Despues hizieron los muchachos de la escuela sus papeles de representazion y danzas, todo con mucha grazia. La Ciudad asistio â todas las funziones tubo fuegos y toros de la tierra $=$

${ }^{194}$ Se zelebran los Jubileos de el mes descubierto el $\mathrm{Sr}$ los terceros Domingos, a que se dio prinzipio el Domingo terzero de Junio de 1695 en Madrid de la horden de N[uestro] Pe Gen[era] ${ }^{195}$ que se alla en el Nicho $1^{\circ}$ de el Archiuo num[er] $16=$

${ }^{196}$ Y por que no es razon dejar de hazer menzion, de aquel, q[ue] desaziendose de sus Yntereses, los ofrezio â su Magèsta $]^{d}$ para fin tan de su agrado como fue la fundazion deste $S^{\text {to }}$ Collegio, â parezido dar notizia de la muerte de Nuestro $\mathrm{S}^{\text {or }}$ fundador $\mathrm{D}^{\mathrm{n}}$ Juan de Urdanegui tan dichosa como la expresa la carta de edificazion que se alla en el Nicho $1^{\circ}$ $\mathrm{n}$ [umer] 24 escrita $\mathrm{p}[\mathrm{o}]^{\mathrm{r}}$ su Confesor el Pe Joseph de Buendia religioso de n[uestr]â Compa en el Collegio de $\mathrm{S}^{\mathrm{n}}$ Pablo de Lima. murio pues el dia 16 de ${ }^{197}$ Nov[iembr] e de 1682 en d[ic]ha Ciudad de lima, hauiendo sido rezeuido en nuestra Compa y echos los tres primeros votos y profesion tres dias antes, con lizencia de su señora esposa. Su cuerpo fue depositado en la Capilla Interior de d[ic]ho Collegio de $\mathrm{S}^{\mathrm{n}}$ Pablo en una caxa de cedro, por auer mandado en su testam[en] to se traxesen sus guesos a este Colle[gi] ${ }^{\circ}$ como se hizo. Dicha $\mathrm{S}^{\text {ra }}$ su esposa mostro tam[bi] ${ }^{\text {en }}$ mucho [Fol. numerado 6v] afecto a este Collegio, y quiso q[ue] despues de sus dias se trajese su corazon como tam[bi] ${ }^{\text {en }}$ se executo.

Estos dos documentos tan similares en su inicio y tan diversos a partir de un punto que ya hemos señalado, tienen claras diferencias y también inconfundibles correspondencias.

Ambos están redactados por un jesuita, por la manera de hablar sobre la Compañía de Jesús, como hemos apuntado más arriba.

El documento base es menos preciso y su escritura más alejada en ortografía de los actuales escritos. El D2 acaba con una frase significativa que nos indica quién es su autor ${ }^{198}$. Habla en primera persona y afirma al final del documento:

194 (Al margen) Jubileos de el mes.

195 Tirso González [Santalla, España 1621-Roma 27.10.1705].

196 (Al margen) Muerte de el Sor fundador.

197 (Al margen) es receuido en la Compa.

198 No podemos afirmar esto de todo el documento, porque, como está indicado en su sitio, cuando la mano de escribiente cambia. Es precisamente esta última mano la que se puede identificar por las razones que aducimos. 
«Assi se lo oy, Luego, que vine, a mi Antecesor el P[adr]e Juan Bauptista Mecoleta.»

Johannes Baptista Mecoleta [Vergara 9.6.1658-la última noticia que aparece en los catálogos es en el año 1730]. Fue Rector de Orduña y su sucesor, que no se menciona a sí mismo fue, según el catálogo de Castilla, Emmanuel de Herrera [Segovia 29.12.1652 - $\dagger$ antes de 1730]. Era Rector de Orduña en el año 1705, en consecuencia es el autor del escrito, por lo menos en lo que se refiere a todo lo que se dice después del párrafo de otra mano, que comienza con el texto: «Murio el Marques, hijo de Nuestro fundados el dia 13 de Mayo del 1702 ... » Acaba con las palabras que hemos citado un poco más arriba señalándonos como su antecesor al P. Juan Bautista Mecoleta. No hay duda que al menos esta parte del D2 sale de la pluma del segoviano jesuita Manuel de Herrera ${ }^{199}$.

Lo mismo que le sucede a Juan Antonio Archimbaud les pasa a estos dos (o quizá tres, porque hay un cambio de letra al final del D2). La narración de la fundación es objetiva y sin especial notoriedad que hubiera que señalar al comienzo, cuando relata las intenciones y cláusulas de la legación de los Fundadores.

Más tarde ambos documentos comienzan a describir poco a poco las incidencias de la fundación, la relación con la Ciudad, los vecinos y el mismo clero.

Este es el momento en el cual ambos documentos salen manifiestamente en defensa de la Compañía de Jesús que, según lo escrito, parece haber obrado siempre con grandeza de miras y extraordinario desprendimiento.

Existe la diferencia del documento aducido como base y del que viene en nota en forma de variantes, porque este segundo es mucho más preciso al relatar nombres y sucesos. Sus afirmaciones resultan más fundamentadas incluso jurídicamente.

En el conflicto originado por la cubierta total de las carnicerías el D2 se justifica ateniéndose al decreto del 25 de abril de 1680, que la parte contraria ataca como resultado de un ayuntamiento parcial y no público de toda la ciudad. Los jesuitas consiguen al final que en ayuntamiento

199 Nótese, aunque sea sólo a título de curiosidad, cómo este superior jesuítico, en la parte del documento que con toda certeza procede de su mano, no hace otra cosa que referir las obras materiales y mejoras que se han realizado bajo su mandato. Por otro lado deja a los eclesiásticos de Orduña (el Cabildo eclesiástico, como le llama él) en una posición un tanto desairada. Por este único escrito podemos deducir que el buen segoviano Manuel Herrera no tenía demasiado espíritu crítico con respecto a su propia gestión. Pero cuando lo aplicaba a otras personas o entidades (nos referimos al Cabildo eclesiástico de Orduña) se muestra demasiado radical y duro. Sobre el autor del D2 véase confirmación en la nota 183, p. 180 donde se afirma que desde el 7.5.1703 el Rector del Colegio de Orduña era el P. Manuel Herrera. 
general del 27 de diciembre de 1689 se ratifique el de 1680, con lo que quedan en paz y posesión de la fama jurídica.

Cosa parecida pasa con la disputa entre Bentura de Zárate, abogado, que exige a los jesuitas que paguen los derechos de aduana de los productos que adquieren de los arrieros (no de los que traen en carretas propias) debiéndolos pasar por el peso real o público de la ciudad con el consiguiente pago.

Los jesuitas se resistieron y acudieron al $n .^{\circ} 3 .^{\circ}$ de la escritura de fundación, justificando su conducta con el parecer de abogados de la corte de Madrid, que nuevamente les colocó en posesión de la razón jurídica.

Todas las diferencias habían sido graves. El pueblo, a pesar de haberlo descrito acudiendo a la función pública y fiestas de S. Ignacio, estaba bastante irritado con la conducta de los jesuitas.

Ambos documentos refieren de los vecinos que:

«... y algunos de ellos levantando los dedos dixeron en Voz alta: nada a la compañia, vayan fuera que no los avemos menester».

Las cuales palabras y gestos son indicios bien claros de que no todo era amor y veneración por la Compañía de Jesús y sus actos de culto.

Por fin en el D2 cuando cambia de mano, el autor se desata en un agrio ataque al clero de la ciudad.

Cuando los jesuitas no estaban durante la Cuaresma, se turnaban un año la ciudad y otro el cabildo eclesiástico para contratar y pagar un predicador. Nuestro buen jesuita autor del documento se desata en ataques a este clero que ahora tiene gratis esa predicación con los padres de la Compañía, se embolsan el dinero, que antes pagaban al predicador importado y luego no acuden a los actos organizados por los jesuitas acabando con el amargo reproche: «no fuera mucho viniessen a las fiestas y visperas sin la expectativa de que les regalan: pero no lo haran.»

\section{CONCLUSIONES GENERALES}

Las fundaciones de los diversos colegios son poco más o menos semejantes. Suelen ser en general producto de testamentos de personas naturales del lugar donde se intenta fundar el Colegio jesuítico.

Para ello dejan un capital, con cuyas rentas se edifica y/o mantiene a los jesuitas que vendrán al Colegio.

Por otro lado también se reciben otras aportaciones, con diversos fines, pero se pueden reducir a los siguientes:

- Ministerios propios de la Compañía de Jesús, predicar, confesar, asistir a moribundos y enfermos. 
—Enseñanza a los niños a leer, escribir y contar, la gramática y la retórica y, a veces, cátedra de teología moral.

- Misiones que se deben impartir generalmente en los pueblos o lugares de origen de los fundadores o alrededores.

- Encargos de misas perpetuas en días señalados.

- Enterramiento de los fundadores y familiares en la Iglesia del Colegio de la Compañía que se intenta fundar. Los fundadores y sus descendientes serán los patronos del Colegio e Iglesia con todos los privilegios que generalmente concede por su Instituto la Compañía a estas personas.

- Por fin, pequeños detalles piadosos, como la vela a los fundadores en ciertos días de fiesta, lámparas de aceite para el Santísimo Sacramento, imágenes y letreros alusivos a los fundadores, misas por los fundadores difuntos y sus familiares.

Desde el punto de vista histórico, así como hemos señalado, el claro partidismo de Juan Antonio Archimbaud y Solano en favor de Carlos III y contra los jesuitas, del mismo modo podríamos señalar un marcado e incoherente a veces deseo de defensa propia por parte de los jesuitas que opinan o redactan documentos como los dos que poseemos, sobre la fundación del Colegio de Orduña.

Sin embargo todos parecen estar conformes en la generosidad de los fundadores, su deseo de promover la piedad y la cultura en su pueblo o villa, generalmente de su origen, sin distinción de personas (como lo hemos señalado en sus debidos lugares). 